\title{
Diurnal regulation of photosynthetic light absorption, electron transport and carbon fixation in two contrasting oceanic environments
}

\author{
Nina Schuback ${ }^{1,2}$ and Philippe D. Tortell ${ }^{2,3}$ \\ ${ }^{1}$ Swiss Polar Institute, École Polytechnique Fédérale de Lausanne, Lausanne, Switzerland \\ ${ }^{2}$ Department of Earth, Ocean, and Atmospheric Sciences, University of British Columbia, Vancouver, Canada \\ ${ }^{3}$ Department of Botany, University of British Columbia, Vancouver, Canada
}

Correspondence: Nina Schuback (schuback.nina@gmail.com)

Received: 21 December 2018 - Discussion started: 17 January 2019

Revised: 4 March 2019 - Accepted: 20 March 2019 - Published: 4 April 2019

\begin{abstract}
Understanding the dynamics of marine phytoplankton productivity requires mechanistic insight into the non-linear coupling of light absorption, photosynthetic electron transport and carbon fixation in response to environmental variability. In the present study, we examined the variability of phytoplankton light absorption characteristics, lightdependent electron transport and ${ }^{14} \mathrm{C}$-uptake rates over a $48 \mathrm{~h}$ period in the coastal subarctic north-east (NE) Pacific. We observed an intricately coordinated response of the different components of the photosynthetic process to diurnal irradiance cycles, which acted to maximize carbon fixation, while simultaneously preventing damage by excess absorbed light energy. In particular, we found diurnal adjustments in pigment ratios, excitation energy transfer to reaction centre II (RCII), the capacity for non-photochemical quenching (NPQ), and the light efficiency $(\alpha)$ and maximum rates $\left(P_{\max }\right)$ of RCII electron transport $\left(\mathrm{ETR}_{\mathrm{RCII}}\right)$ and ${ }^{14} \mathrm{C}$ uptake. Comparison of these results from coastal waters to previous observations in offshore waters of the subarctic NE Pacific provides insight into the effects of iron limitation on the optimization of photosynthesis. Under iron-limited, lowbiomass conditions, there was a significant reduction of ironrich photosynthetic units per chlorophyll $a$, which was partly offset by higher light absorption and electron transport per photosystem II (PSII). Iron deficiency limited the capacity of phytoplankton to utilize peak midday irradiance for carbon fixation and caused an upregulation of photoprotective mechanisms, including NPQ, and the decoupling of light absorption, electron transport and carbon fixation. Such decoupling resulted in an increased electron requirement $\left(\Phi_{e, C}\right)$
\end{abstract}

and decreased quantum efficiency $\left(\Phi_{\mathrm{C}}\right)$ of carbon fixation at the iron-limited station. In both coastal and offshore waters, $\Phi_{\mathrm{e}, \mathrm{C}}$ and $\Phi_{\mathrm{C}}$ correlated strongly to NPQ, albeit with a significantly different slope. We discuss the implications of our results for the interpretation of bio-optical data and the parameterization of numerical productivity models, both of which are vital tools in monitoring marine photosynthesis over large temporal and spatial scales.

\section{Introduction}

It is well known that photosynthetic performance and lightharvesting characteristics of phytoplankton vary widely across environmental conditions and seasonal cycles (e.g. Falkowski and Raven, 2007; Geider et al., 2001; Harris, 1986; Kirk, 1994). On physiological scales, these changes can be observed as rapid metabolic adjustments occurring over seconds to hours, while on ecological scales (days to months) they are manifested as phytoplankton species succession. These physiological and ecological responses are ultimately driven by the integrated growth environment experienced by phytoplankton and the need to optimize the conversion of light energy to carbon biomass, while preventing damage from supersaturating light. The present study was designed to improve the mechanistic understanding of the entire photosynthetic process in marine phytoplankton and its capacity to respond to environmental variability. Such information is necessary to understand and predict ongoing 
climate impacts associated with changes in nutrient supply, temperature and irradiance levels on marine photosynthetic carbon fixation (e.g. Behrenfeld et al., 2006, 2016; HoeghGuldberg and Bruno, 2010; Taucher and Oschlies, 2011).

The photosynthetic process comprises a chain of diverse reactions, leading from light absorption via electron transport to photosynthate (ATP and NADPH) production and carbon fixation (Fig. 1). These reactions, operating on vastly different timescales (e.g. Huner et al., 1998), are ultimately powered by solar energy and depend critically on nutrient availability. Variability in surface ocean nutrient concentrations results from physical mixing and biological consumption acting on scales of days to months. By comparison, variability in light intensity occurs over a broader range of timescales, with rapid transients induced by atmospheric variability (e.g. cloud cover) and fine-scale mixing, superimposed on diel and seasonal cycles. Importantly, while light energy is an absolute requirement for the photosynthetic process, excess irradiance, even on short timescales, can lead to photodamage and photoinhibition (Powles, 1984).

To compensate for fluctuations in light availability, marine phytoplankton have evolved extreme photo-physiological plasticity, allowing cells to maximize light-harvesting capacity at low irradiance, while minimizing photodamage under high light levels. A better mechanistic understanding of the scope and limits of such coordinated regulation within the photosynthetic process is essential for the accurate modelling of bottom-up controls on marine primary productivity and its response to environmental change. Furthermore, mechanistic insight into environmental controls on the light use efficiency of carbon fixation is crucial for the development of algorithms estimating primary productivity from remotely acquired optical data (Lee et al., 2015; Silsbe et al., 2016; Zoffoli et al., 2018).

In the present study, we examined diurnal variability in the capacity of phytoplankton to use light energy for biomass production in a productive coastal upwelling regime. Hightemporal-resolution measurements, conducted over a $48 \mathrm{~h}$ period, revealed coordinated changes in light absorption, energy dissipation, photosynthetic electron transport and ${ }^{14} \mathrm{C}$ uptake. Our results demonstrate strong variability in the stoichiometry of various components of the photosynthetic process, providing insight into phytoplankton metabolic acclimation potential in response to environmental fluctuation in coastal waters. Comparison of these new results with previous observations in the iron-limited subarctic north-east (NE) Pacific (Schuback et al., 2016) allowed us to identify distinct diurnal patterns in these contrasting environments, yielding insight into the effects of iron limitation on various components of the photosynthetic process and their coupling over diurnal irradiance cycles. Most significantly, our data demonstrate a limited capacity of iron-limited phytoplankton to buffer fluctuations in light availability, resulting in an increased need for photoprotection. This enhanced photoprotection is achieved through alterations in pigment ratios and

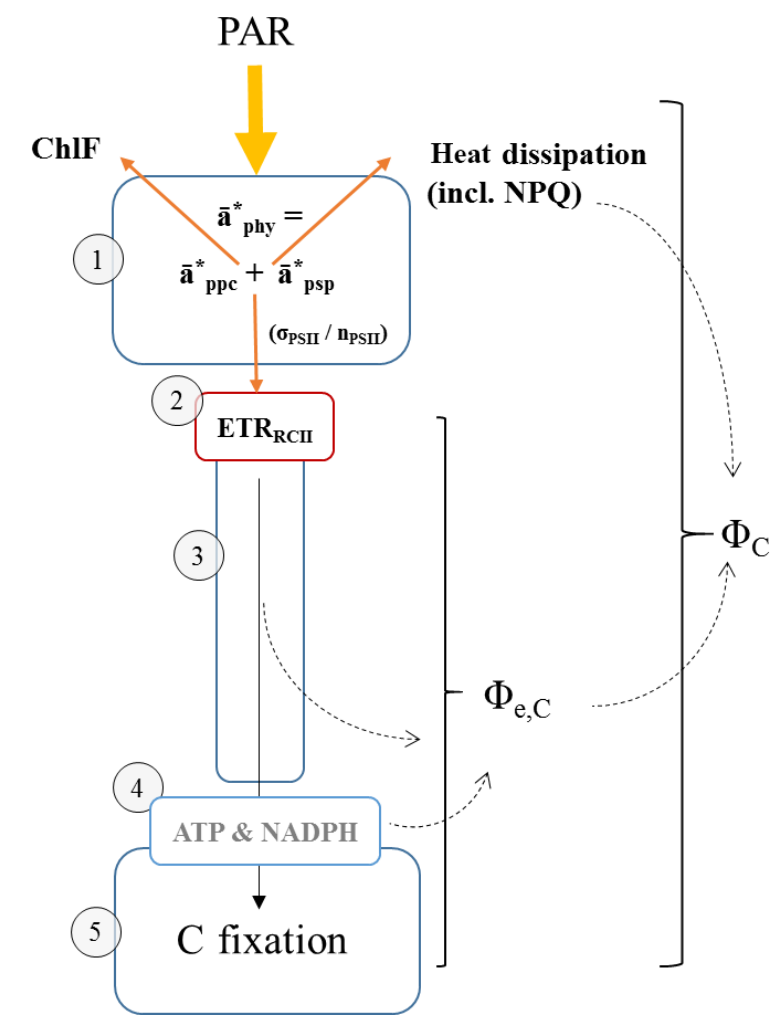

Figure 1. Schematic diagram of the photosynthetic process, highlighting rates, variables and conversion factors measured or derived during this study. (1) Light absorption: photosynthetically available radiation (PAR, $400-700 \mathrm{~nm}$ ) is absorbed by phytoplankton $\left(\bar{a}_{\mathrm{phy}}^{*}, \mathrm{~m}^{-2} \mathrm{mgChl} a^{-1}\right)$. Total absorption by phytoplankton can be subdivided into absorption by photosynthetic pigments $\left(\bar{a}_{\mathrm{psp}}^{*}, \mathrm{~m}^{-2} \mathrm{mg} \mathrm{Chl} a^{-1}\right)$ and photoprotective carotenoids $\left(\bar{a}_{\mathrm{ppc}}^{*}\right.$, $\mathrm{m}^{-2} \mathrm{mg} \mathrm{Chl} a^{-1}$ ). The parameter $\bar{a}_{\mathrm{psp}}^{*}$, if specific for PSII (photosystem II) only, can be further decomposed into values of the functional absorption cross section of each RCII (reaction centre II) in the dark-regulated state, i.e. not affected by NPQ ( $\sigma_{\mathrm{PSII}}$, $\AA^{2} \mathrm{RCII}^{-1}$ ) and the number of functional RCII per Chl $a$ (n $\mathrm{PSII}$, RCII Chl $a^{-1}$ ). Both $\sigma_{\text {PSII }}$ and n $n_{\text {PSII }}$ can be adjusted to regulate the amount of excitation energy reaching RCII. The light energy absorbed by the pigments of PSII can have three fates: photochemistry $\left(\mathrm{ETR}_{\mathrm{RCII}}\right)$, dissipation as heat (including the upregulation of $\mathrm{NPQ}$ ) and re-emission as fluorescence (ChlF). Changes in ChlF can be used to infer changes in the other two pathways. (2) Initial charge separation in RCII (ETR RCII, mol e $\left.\mathrm{e}^{-} \mathrm{mol} \mathrm{RCII}^{-1} \mathrm{~s}^{-1}\right)$. (3) Electron transport after initial charge separation in RCII ultimately leads to the generation of "photosynthate" ((4) ATP and NADPH), which in turn can be used for carbon fixation $((5) \mathrm{C}$ fixation, here measured as ${ }^{14} \mathrm{C}$ uptake). The electron requirement of carbon fixation $\Phi_{\mathrm{e}, \mathrm{C}}\left(\mathrm{mol} \mathrm{e}^{-} \mathrm{mol} \mathrm{RCII}^{-1}\right)$ is the ratio of electrons displaced by the initial charge separation in RCII to ${ }^{14} \mathrm{C}$ uptake. The photosynthetic efficiency, $\Phi_{\mathrm{C}}\left(\mathrm{mol} \mathrm{C}\right.$ mol quanta $\left.{ }^{-1}\right)$, is the amount of ${ }^{14} \mathrm{C}$ fixed per quanta absorbed. Under conditions when the rate of light absorption and delivery to RCII surpasses the potential for carbon fixation or reductant formation, both $\Phi_{\mathrm{e}, \mathrm{C}}$ and NPQ will increase to prevent over-reduction of RCII. The magnitude of $\Phi_{C}$, in turn, is dependent on how much initially absorbed energy is dissipated as fluorescence (ChlF) and heat (including NPQ) as well as through processes decoupling ETR $_{\mathrm{RCII}}$ from ${ }^{14} \mathrm{C}$ uptake (reflected in $\Phi_{\mathrm{e}, \mathrm{C}}$ ). 


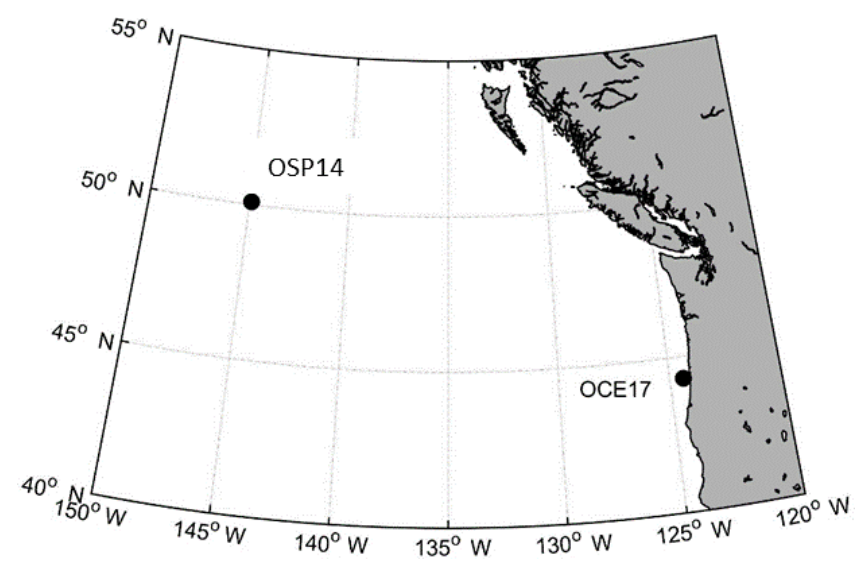

Figure 2. Map of the subarctic NE Pacific showing location of OSP14, in offshore iron-limited waters, and OCE17, a coastal upwelling region.

light absorption characteristics, an increased potential for heat dissipation of excess energy (NPQ) and decoupling of the different components of the photosynthetic process, leading to reduced light use efficiency. Based on our results, we discuss the correlation between photosynthetic light use efficiency and NPQ, an optical signal amiable to high-resolution acquisition by autonomous sensors.

\section{Methods}

In the present study, we examined light-dependent diurnal variability in different components of the photosynthetic process in marine phytoplankton. We present new results from a 2017 research expedition in high-productivity coastal upwelling waters and compare these data to recently published observations from the iron-limited waters of the subarctic $\mathrm{Pa}$ cific Ocean (Schuback et al., 2016). We first introduce the two datasets and then briefly describe the methods used to assess each component of the photosynthetic process (Fig. 1), from light absorption to carbon fixation.

\subsection{Dataset 1}

New field data were collected during a $48 \mathrm{~h}$ period from 19 to 21 August 2017 on board the R/V Oceanus in the subarctic NE Pacific. During this period, the research vessel followed a Lagrangian drifter equipped with a drogue sock at $5 \mathrm{~m}$ depth in order to track mean surface layer flow. The drifter was deployed approximately 25 nautical miles off the coast of Oregon, USA ( $44.3^{\circ} \mathrm{N}, 124.4^{\circ} \mathrm{W}$; Fig. 2). More information on the drifter study is available in Herr et al. (2019).

Seawater samples were collected from the ship's underway water supply (intake depth approx. $5 \mathrm{~m}$ ) and used for photophysiological measurements by fast repetition rate fluorometry (FRRF; $2 \mathrm{~h}$ intervals) ${ }^{14} \mathrm{C}$-uptake experiments, pigment analysis by HPLC (high-performance liquid chromatogra- phy) and particulate light absorption ( $4 \mathrm{~h}$ intervals). Sample collection, handling and experimental protocols were identical to the methods used in Schuback et al. (2016). In the following, we provide only brief details about sample analysis and rate measurements, with emphasis on approaches that extend beyond the analysis of Schuback et al. (2016). All measured variables and derived parameters are summarized in Table 1.

In addition to the discrete sample measurements described above, we acquired a number of additional datasets from various sensors connected to the ship's underway water supply. All measurements and sensors used on board the R/V Oceanus are summarized in Table S1.1 in the Supplement (OCE17 data set). Seawater surface temperature and salinity were measured by a thermosalinograph (SBE 45 and SBE 38 for salinity and temperature, respectively), while surface PAR (400-700 nm) was continuously logged using a Satlantic PAR sensor mounted on the ship's superstructure. We used a Soliense fast repetition rate fluorometer to continuously measure photo-physiological parameters derived from single-turnover induction protocols (see Sect. 3.5). In addition, we used the WetLabs ac-s to quantify light attenuation and absorption $(400-750 \mathrm{~nm})$, following the protocols described in Burt et al. (2018).

\subsection{Dataset 2}

In a previous study (Schuback et al., 2016), we assessed variability and coupling of different components of the photosynthetic process in an iron-limited phytoplankton assemblage at Ocean Station Papa in the subarctic north-east Pacific $\left(50^{\circ} \mathrm{N}, 145^{\circ} \mathrm{W}\right.$, Fig. 2$)$. During this earlier study, conducted in June 2014, and hereafter referred to as OSP14, seawater samples collected from the vessel's underway water supply (intake depth approx. $5 \mathrm{~m}$ ) were used for photo-physiological measurements by FRRF ( $3 \mathrm{~h}$ intervals), ${ }^{14} \mathrm{C}$-uptake experiments ( $3 \mathrm{~h}$ intervals), pigment analysis by HPLC ( $6 \mathrm{~h}$ intervals) and particulate light absorption ( $3 \mathrm{~h}$ intervals). All measurements taken are summarized in Table S1.2, and full details of sample handling, experimental protocols and instrumentation can be found in Schuback et al. (2016). In several instances, the dataset presented in Schuback et al. (2016) was reanalyzed, as described below.

\subsection{Absorption spectra}

Phytoplankton absorption spectra $\left(a_{\text {phy }}(\lambda)\right)$ were determined following the quantitative filter technique (QFT) of Mitchell et al. (2000) with path length amplification estimates following Bricaud and Stramski (1990), as described in detail in Schuback et al. (2017). All absorption spectra were corrected for an overestimation of absorption at short wavelengths following the approach suggested by Letelier et al. (2017) and described in Supplement S2. To determine chlorophyll $a$ specific absorption spectra $\left(a_{\text {phy }}^{*}(\lambda), \mathrm{m}^{2} \mathrm{mg} \mathrm{Chl} a^{-1}\right)$, ab- 
Table 1. List of parameters derived and discussed in the text.

\begin{tabular}{|c|c|c|c|}
\hline \multicolumn{2}{|r|}{ Parameter } & \multirow{2}{*}{$\begin{array}{l}\text { Units } \\
\mathrm{m}^{2} \mathrm{mgChl} a^{-1}\end{array}$} & \multirow{2}{*}{$\begin{array}{l}\text { Method } \\
\text { QFT with correction following Letelier et al. (2017). }\end{array}$} \\
\hline$a_{\mathrm{phy}-\mathrm{QFT}}^{*}(\lambda)$ & Phytoplankton absorption spectra & & \\
\hline$a_{x x-\operatorname{HPLC}}^{*}(\lambda)$ & $\begin{array}{l}\text { Absorption spectra ( } x x \text { specifies phytoplank- } \\
\text { ton, photosynthetic pigments or photoprotective } \\
\text { carotenoids) }\end{array}$ & $\mathrm{m}^{2} \mathrm{mg} \mathrm{Chl} a^{-1}$ & HPLC spectral reconstruction with packaging correction. \\
\hline$\hat{a}_{x x}^{*}$ & Absorption coefficient & $\mathrm{m}^{2} \mathrm{mgChl} a^{-1}$ & $\begin{array}{l}\text { Mean absorption } 400-700 \mathrm{~nm} \text { specific to flat white excitation } \\
\text { light. }\end{array}$ \\
\hline $\bar{a}_{x x}^{*}$ & Weighted absorption coefficient & $\mathrm{m}^{2} \mathrm{mgChl} a^{-1}$ & $\begin{array}{l}\text { Mean absorption } 400-700 \mathrm{~nm} \text { weighted to spectral distribution } \\
\text { of in situ light. }\end{array}$ \\
\hline$\sigma_{\mathrm{PSII}}$ & Functional absorption cross section & $\AA^{2} \mathrm{RCII}^{-1}$ & $\begin{array}{l}\text { FRRF ST protocol during dark-regulated state, value specific to } \\
\lambda \text { of excitation source. }\end{array}$ \\
\hline$\sigma_{\text {PSII-IS }}$ & Functional absorption cross section & $\AA^{2} \mathrm{RCII}^{-1}$ & As above, value corrected to be specific to in situ light spectrum. \\
\hline$\sigma_{\text {PSII-IS }}^{\prime}$ & Functional absorption cross section & $\AA^{2} \mathrm{RCII}^{-1}$ & $\begin{array}{l}\text { FRRF ST protocol during light-regulated state, value corrected } \\
\text { to in situ light spectrum. }\end{array}$ \\
\hline$F_{v} / F_{m}$ & Quantum efficiency of initial charge separation & No units & FRRF ST protocol during dark-regulated state; $\left(F_{m}-F_{o}\right) / F_{m}$. \\
\hline$F_{q}^{\prime} / F_{v}^{\prime}(500)$ & $\begin{array}{l}\text { Fraction of RCII which remains open }\left(Q_{A} \text { oxi- }\right. \\
\text { dized) at a background irradiance } \\
\text { of } 500 \mu \mathrm{mol} \text { quanta } \mathrm{m}^{-2} \mathrm{~s}^{-1}\end{array}$ & No units & $\begin{array}{l}\text { FRRF ST protocol during light-regulated state; }\left(F_{m}^{\prime}-\right. \\
\left.F^{\prime}\right) /\left(F_{m}^{\prime}-F_{o}^{\prime}\right) .\end{array}$ \\
\hline $\mathrm{NPQ}_{\mathrm{NSV}}$ & $\begin{array}{l}\text { Non-photochemical quenching at in situ light } \\
\text { intensity at the time and depth of sampling }\end{array}$ & No units & FRRF ST protocol during light-regulated state; $F_{o}^{\prime} /\left(F_{m}^{\prime}-F_{o}^{\prime}\right)$. \\
\hline $\mathrm{NPQ}_{\mathrm{NSV}}(500)$ & $\begin{array}{l}\text { Non-photochemical quenching for a reference } \\
\text { light intensity of } 500 \mu \text { mol quanta } \mathrm{m}^{-2} \mathrm{~s}^{-1}\end{array}$ & No units & As above. \\
\hline $1 / n_{\text {PSII }}$ & Photosynthetic unit size of PSII & $\mathrm{molChl} a \mathrm{~mol} \mathrm{RCII}^{-1}$ & Estimated from $\bar{a}_{\mathrm{psp}}^{*}$ and $\sigma_{\mathrm{PSII}-\mathrm{IS}}$ \\
\hline $\mathrm{ETR}_{\mathrm{RCII}}$ & Rate of initial charge separation in RCII & $\mathrm{mol} \mathrm{e}^{-} \mathrm{mol} \mathrm{RCII}^{-1} \mathrm{~s}^{-1}$ & $\begin{array}{l}\text { Calculated from FRRF ST protocol derived parameters as } E \text {. } \\
\sigma_{\text {PSII-IS }}^{\prime} \cdot F_{q}^{\prime} / F_{v}^{\prime} \text {. }\end{array}$ \\
\hline $\mathrm{ETR}_{\mathrm{RCII}}-P_{\max }$ & Maximum light-saturated rate & $\mathrm{mol} \mathrm{e}^{-} \mathrm{mol} \mathrm{RCII}^{-1} \mathrm{~s}^{-1}$ & $\begin{array}{l}\text { As above, but maximum rate of ETR achieved during } \\
\text { light-response curve. }\end{array}$ \\
\hline $\mathrm{ETR}_{\mathrm{RCII}}-\alpha$ & Light efficiency under light limitation & $\begin{array}{l}\mathrm{mol} \mathrm{e}^{-} \text {mol RCII } \\
\left(\mu \mathrm{mol} \text { quanta } \mathrm{m}^{-2} \mathrm{~s}^{-1}\right)^{-1}\end{array}$ & As above, but initial slope of light-response ETR curve. \\
\hline${ }^{14} \mathrm{C}$ uptake & Rate of carbon fixation & $\operatorname{molCmol~Chl~} a^{-1} \mathrm{~s}^{-1}$ & $\begin{array}{l}2 \mathrm{~h}{ }^{14} \mathrm{C} \text {-uptake light-response curves measured at each time } \\
\text { point. }\end{array}$ \\
\hline${ }^{14} \mathrm{C}-P_{\max }$ & Maximum light-saturated rate & $\mathrm{molCmol} \mathrm{Chl} a^{-1} \mathrm{~s}^{-1}$ & $\begin{array}{l}\text { As above, but maximum rate of }{ }^{14} \mathrm{C} \text { uptake achieved during } \\
\text { light-response curve. }\end{array}$ \\
\hline${ }^{14} \mathrm{C}-\alpha$ & Light efficiency under light limitation & $\begin{array}{l}\text { mol C mol Chl } a^{-1} \mathrm{~s}^{-1} \\
\left(\mu \mathrm{mol} \text { quanta } \mathrm{m}^{-2} \mathrm{~s}^{-1}\right)^{-1}\end{array}$ & As above, but initial slope of ${ }^{14} \mathrm{C}$-uptake light-response curve. \\
\hline$E_{\mathrm{k}}$ & Light saturation parameter & $\mu \mathrm{mol}$ quanta $\mathrm{m}^{-2} \mathrm{~s}^{-1}$ & $\begin{array}{l}\text { Point of saturation during light-response curve }\left(P_{\max } / \alpha\right) \text { of } \\
\text { ETR or }{ }^{14} \mathrm{C} \text { uptake. }\end{array}$ \\
\hline$\Phi_{\mathrm{e}, \mathrm{C}}$ & Electron requirement for carbon fixation & $\mathrm{mole}^{-} \mathrm{molC}^{-1}$ & Calculated from ETR and ${ }^{14} \mathrm{C}$-uptake rates. \\
\hline$\Phi_{\mathrm{C}}$ & Quantum efficiency of carbon fixation & mol C mol quanta $^{-1}$ & Calculated from light absorption and ${ }^{14} \mathrm{C}$-uptake rates. \\
\hline
\end{tabular}

sorption values were normalized to corresponding HPLCderived [TChl $a$ ]. The Chl $a$-specific phytoplankton absorption coefficient $(400-700 \mathrm{~nm})$ was calculated for a flat white spectrum $\left(\hat{a}_{\mathrm{phy}}^{*}\right)$ and weighted to the spectrum of available light in situ $\left(\bar{a}_{\text {phy }}^{*}\right)$ as described in Babin et al. (1996).

\subsection{Pigment analysis and spectral reconstruction}

Collection and analysis of HPLC pigment samples was performed following the method of Pinckney (2013), as described in detail in Schuback et al. (2016). Pigment concentrations determined by HPLC and weight-specific absorption spectra provided by Bidigare et al. (1990) were used for reconstruction of phytoplankton light absorption spectra $\left(a_{\text {phy }}^{*}(\lambda)\right)$. This approach estimates absorption spectra specific to photosynthetic pigments $\left(a_{\mathrm{psp}}^{*}(\lambda)\right)$ and photoprotective carotenoids $\left(a_{\mathrm{ppc}}^{*}(\lambda)\right)$. Following the approach described in Le et al. (2009) and Letelier et al. (2017), absorption spectra were further corrected for pigment packaging effects using a wavelength-specific estimate of packaging developed by Morel and Bricaud (1981), with a size parameter calculated from an empirical relationship to chlorophyll $a$ concentration ([Chl a]) (Woźniak et al., 1999). As described in the Supplement (S2), we found good agreement between re- 
sults from the spectral reconstruction and QFT approaches $\left(R^{2}=0.95, n=20\right)$.

\subsection{FRRF-derived photo-physiology}

Single-turnover induction curves of Chl $a$ fluorescence (ChlF) yields were measured on a bench-top FRRF instrument (Soliense Instruments), after acclimation of samples to low light intensities $\left(<10 \mu\right.$ mol quanta $\left.\mathrm{m}^{-2} \mathrm{~s}^{-1}\right)$ for $20 \mathrm{~min}$. Blank correction, derivation of ChlF yields and parameters, estimation of electron transport in reaction centre II $\left(\mathrm{ETR}_{\mathrm{RCII}}, \mathrm{mol} \mathrm{e}^{-} \mathrm{mol} \mathrm{RCII} \mathrm{s}^{-1}\right.$ ) and fitting of ETR $\mathrm{RCII}_{\text {light- }}$ response curves were performed as described in Schuback et al. (2016, 2017). We derived values of the maximum lightsaturated capacity of ETR $\mathrm{RCII}\left(\mathrm{ETR}_{\mathrm{RCII}}-P_{\max }\right)$, the lightdependent increase in $\mathrm{ETR}_{\mathrm{RCII}}\left(\mathrm{ETR}_{\mathrm{RCII}}-\alpha\right)$, and rates for the in situ light intensity at the time and depth of sampling (Table 1).

We derived values of the minimum and maximum ChlF yields in the dark-regulated state $\left(F_{o}, F_{m}\right)$ and in each lightregulated state of the light-response curve $\left(F^{\prime}, F_{m}^{\prime}\right)$. The parameter $F_{o}^{\prime}$, which represents the minimum ChlF yield in the absence of photochemical quenching but presence of nonphotochemical quenching, was estimated following Oxborough and Baker (1997). Chl $a$ fluorescence yields were used to estimate the ChlF parameter $F_{v} / F_{m}\left(=\left[F_{m}-F_{o}\right] / F_{m}\right)$; the maximum efficiency of absorbed light used for photochemistry, $F_{q}^{\prime} / F_{m}^{\prime}\left(=\left[F_{m}^{\prime}-F^{\prime}\right] / F_{m}^{\prime}\right)$; the effective efficiency of absorbed light being used for photochemistry; and $F_{q}^{\prime} / F_{v}^{\prime}$ $\left(=\left[F_{m}^{\prime}-F^{\prime}\right] /\left[F_{m}^{\prime}-F_{o}^{\prime}\right]\right)$, an estimate of the fraction of RCII in the 'open' state (Table 1). The functional absorption cross section of RCII was derived in the dark-regulated ( $\sigma_{\mathrm{PSII}}$, $\left.\AA \mathrm{RCII}^{-1}\right)$ and light-regulated state $\left(\sigma_{\mathrm{PSII}}^{\prime}, \AA \mathrm{RCII}^{-1}\right)$ and spectrally corrected to the spectral quality of in situ light $(\sigma$ PSII-IS $)$, as described below. Non-photochemical quenching was estimated as normalized Stern-Volmer quenching, $\mathrm{NPQ}_{\mathrm{NSV}}\left(=F_{o}^{\prime} / F_{v}^{\prime}\right)$, for each light level of the light-response curves (McKew et al., 2013).

We note that the bio-physical model we used to derive photo-physiological parameters from FRRF measurements (Kolber and Falkowski, 1993; Kolber et al., 1998) is not likely to be equally accurate for all phytoplankton species within mixed in situ assemblages. Similarly, the fully darkregulated state, necessary for the calculation of most ChlF parameters, is difficult to achieve in mixed assemblages consisting of species of varying NPQ mechanisms and capacities. As a result, the derived parameters represent best-guess average values for taxonomically diverse phytoplankton assemblages.

\subsection{Photosynthetic unit size of PSII}

We estimated absolute values of the photosynthetic unit size of PSII $\left(1 / n_{\text {PSII }}\right.$, mol Chl $a$ mol RCII $\left.{ }^{-1}\right)$ following the approach suggested by Suggett et al. (2004). In this approach,
$1 / n_{\mathrm{PSII}}$ is obtained from FRRF-derived dark-regulated $\sigma_{\mathrm{PSII}}$ $\left(\AA^{2} \mathrm{RCII}^{-1}\right)$ and photosynthetic pigment absorption spectra, $a_{\mathrm{psp}}^{*}\left(\mathrm{~m}^{2} \mathrm{mg} \mathrm{Chl} a^{-1}\right)$, estimated using the pigment reconstruction approach.

$1 / n_{\mathrm{PSII}}=\frac{\sigma_{\mathrm{PSII}}}{\bar{a}_{\mathrm{psp}}^{*}} \cdot 0.013453$

Here, both $\sigma_{\mathrm{PSII}}$ and $\bar{a}_{\mathrm{psp}}^{*}$ are specific to the spectral distribution of the FRRF excitation LED. The factor 0.013453 converts milligrams of Chl $a$ to mol Chl $a, \AA^{2}$ to $\mathrm{m}^{2}$, and RCII to mol RCII, and it is assumed that $50 \%$ of absorbed photons go to PSII (e.g. Kromkamp and Forster, 2003). The error introduced by this assumption is difficult to assess, though it should be dependent on species composition, and is unlikely to be greater than $20 \%$ (Suggett et al., 2004).

\section{$2.7{ }^{14} \mathrm{C}$ uptake}

Rates of ${ }^{14} \mathrm{C}$ uptake were measured using small volume $(20 \mathrm{~mL}), 2 \mathrm{~h}$ light-response curves in a custom-built photosynthetron. Full details of the experimental procedure, calculation of rates and fitting of light-response curves can be found in Schuback et al. (2016, 2017). As for light-response curves of ETR $_{\mathrm{RCII}}$, we derived values of the maximum lightsaturated capacity of ${ }^{14} \mathrm{C}$ uptake $\left({ }^{14} \mathrm{C}-P_{\max }\right)$ and the lightdependent increase in ${ }^{14} \mathrm{C}$ uptake $\left({ }^{14} \mathrm{C}-\alpha\right)$. From these two parameters, we were able to derive ${ }^{14} \mathrm{C}$-uptake rates for the in situ light intensity at the time and depth of sampling (Table 1), using the exponential model of Webb et al. (1974).

Multiple studies have demonstrated that short-term ${ }^{14} \mathrm{C}$ uptake experiments, as employed here, measure an intermediate quantity between gross and net production (Halsey and Jones, 2015; Milligan et al., 2015; Pei and Laws, 2013). For fast-growing, nutrient-replete phytoplankton (OCE17 in this study), a larger fraction of the initially fixed ${ }^{14} \mathrm{C}$ will be retained in a transient $\mathrm{C}$ pool for longer, such that the measured rate will be closer to gross productivity. For slow-growing, nutrient-limited phytoplankton (OSP14 in this study) the turnover time of this transient $\mathrm{C}$ pool is very fast, such that more of the initially fixed ${ }^{14} \mathrm{C}$ will be respired, and short incubation times will estimate rates closer to net productivity. It is therefore likely that our derived ${ }^{14} \mathrm{C}$-uptake rates at OSP14 are underestimated (closer to a net rate) relative to OCE17 (closer to a gross rate). This complicates the comparison of absolute ${ }^{14} \mathrm{C}$-uptake rates between the sites in the present study but does not significantly change our conclusions regarding differences in the diel cycle of photosynthetic processes.

\subsection{Spectral correction and derivation of stoichiometries}

The spectral distribution of light at $5 \mathrm{~m}$ depth $\left(E_{\text {is }}(\lambda)\right)$ was estimated as described in Schuback et al. $(2016,2017)$. Prior to curve fitting, absolute values of light intensity used for 
light-response curves of ${ }^{14} \mathrm{C}$ uptake and $\operatorname{ETR}_{\mathrm{RCII}}\left(E_{\mathrm{LED}}(\lambda)\right)$ were corrected relative to the phytoplankton light absorption spectrum.

$$
E_{\mathrm{IS}}=E_{\mathrm{LED}} \cdot \frac{\sum_{400}^{700} a_{\text {phy }}(\lambda) E_{\mathrm{LED}}(\lambda) \cdot \sum_{400}^{700} E_{\mathrm{IS}}(\lambda)}{\sum_{400}^{700} a_{\text {phy }}(\lambda) E_{\mathrm{IS}}(\lambda) \cdot \sum_{400}^{700} E_{\mathrm{LED}}(\lambda)}
$$

Here, $a_{\text {phy }}(\lambda)$ is the phytoplankton absorption spectrum derived from the QFT approach. Values of $\sigma_{\mathrm{PSII}}$, which are specific to the spectral distribution of excitation and background light in the FRRF instrument $\left(E_{\mathrm{LED}}(\lambda)\right)$, were corrected to the in situ spectral light distribution at the time and depth of sampling $\left(E_{\mathrm{IS}}(\lambda)\right)$ using the same approach.

The electron requirement for carbon fixation $\left(\Phi_{\mathrm{e}, \mathrm{C}}, \mathrm{mol} \mathrm{e}^{-} \mathrm{molC}^{-1}\right.$, Fig. 1) was calculated by deriving $\mathrm{Chl} a$-specific rates of electron transport from $\mathrm{ETR}_{\mathrm{RCII}}\left(\mathrm{mol} \mathrm{e}^{-} \mathrm{molRCII}^{-1} \mathrm{~s}^{-1}\right)$ and $1 / n_{\text {PSII }}$ (mol Chl $a$ mol RCII $^{-1}$ ) and dividing these rates by $\mathrm{Chl} a$ specific rates of ${ }^{14} \mathrm{C}$ uptake ( $m o l \mathrm{C} \mathrm{mol} \mathrm{Chl} a^{-1} \mathrm{~s}^{-1}$ ).

$\Phi_{\mathrm{e}, \mathrm{C}}=\frac{\mathrm{ETR}_{\mathrm{RCII}} / n_{\mathrm{PSII}}}{{ }^{14} \mathrm{C} \text { uptake }}$

The minimum value of $\Phi_{\mathrm{e}, \mathrm{C}}$, encountered during light limitation, was calculated using $\alpha$ values of each rate. The quantum efficiency of carbon fixation $\left(\Phi_{\mathrm{C}}, \mathrm{mol} \mathrm{C} \mathrm{mol}\right.$ photon absorbed ${ }^{-1}$, Fig. 1) was calculated from ${ }^{14} \mathrm{C}$ uptake (mg Cmg Chl $a^{-1} \mathrm{~h}^{-1}$ ) and the product of $a_{\mathrm{phy}}^{*}(\lambda)$ $\left(\mathrm{m}^{2} \mathrm{mg} \mathrm{Chl} a^{-1}\right.$ ) and $E_{\mathrm{IS}}(\lambda)$ ( $\mu \mathrm{mol}$ quanta $\mathrm{m}^{-2} \mathrm{~s}^{-1}$ ) as

$\Phi_{\mathrm{C}}=\frac{{ }^{14} \mathrm{C} \text { uptake }}{\sum_{400}^{700} a_{\mathrm{phy}}^{*}(\lambda) E_{\mathrm{IS}}(\lambda)} \cdot 0.023129$.

The maximum photosynthetic efficiency, $\Phi_{\mathrm{C}-\max }$, which is achieved under light-limiting conditions, was calculated from ${ }^{14} \mathrm{C}-\alpha \quad\left(\mathrm{mgCmgChl} a^{-1} \mathrm{~h}^{-1}\right.$ [ $\mu$ mol quanta $\left.\left.\mathrm{m}^{-2} \mathrm{~s}^{-1}\right]^{-1}\right)$ and $\bar{a}_{\text {phy }}^{*}\left(\mathrm{~m}^{2} \mathrm{mg} \mathrm{Chl} a^{-1}\right)$

$\Phi_{\mathrm{C}-\max }=\frac{{ }^{14} \mathrm{C}-\alpha}{a_{\mathrm{phy}}^{*}} \cdot 0.023129$.

The conversion factor converts hours to seconds, $\mu \mathrm{mol}$ to mol, and $\mathrm{mg} \mathrm{C}$ to mol $\mathrm{C}$.

Note that $\Phi_{C}$ represents the quantum efficiency of carbon fixation ( $\mathrm{molC} \mathrm{mol} \mathrm{photon}{ }^{-1}$ ), while $\Phi_{\mathrm{e}, \mathrm{C}}$ is generally defined as the electron requirement of carbon fixation $\left(\mathrm{mol} \mathrm{e}^{-} \mathrm{molC}^{-1}\right)$.

\section{Results and discussion}

In the following, we first describe the diurnal variability of the photosynthetic process during the OCE17 experiment, from light absorption, via electron transport to carbon fixation (Fig. 1). We then compare the observed values and diurnal trends from this coastal upwelling regime to results obtained from a similar study in an iron-limited low-biomass region (OSP14). Based on this comparative analysis, we discuss the environmental controls on the regulation of the photosynthetic process, the magnitude and variability of the electron requirement and quantum efficiency of carbon fixation ( $\Phi_{\mathrm{e}, \mathrm{C}}$ and $\Phi_{\mathrm{C}}$, respectively), and the potential to use NPQ measurements as a proxy for these important parameters.

\subsection{Photosynthetic components and their diurnal periodicity during $\mathrm{OCE} 17$}

Light absorption characteristics and PSII photo-physiology for the $48 \mathrm{~h}$ diurnal cycle at OCE17 are summarized in Table 2. During our intensive sampling period, Chl $a$ biomass, derived from ac-s $676 \mathrm{~nm}$ absorption light height calibrated to HPLC [TChl $a$ ], remained relatively constant $(1.08 \pm$ $\left.0.15 \mu \mathrm{g} \mathrm{L}^{-1}\right)$. Derived values of $1 / n_{\mathrm{PSII}}$ ranged from 284 to $446 \mathrm{~mol} \mathrm{Chl} a \mathrm{~mol} \mathrm{RCII}^{-1}$, which is within the range of values measured in nutrient-replete cultures and field assemblages using the oxygen flash yield approach (e.g. Table 2 in Suggett et al., 2010). We observed no diurnal periodicity in the derived values of $1 / n_{\text {PSII }}$, indicating that the number of functional RCII was not reduced by severe photodamage during high midday irradiances (Table 2).

Phytoplankton absorption coefficients derived from QFT $\left(\hat{a}_{\mathrm{phy}}^{*}\right)$ ranged from 0.012 to $0.017 \mathrm{~m}^{2} \mathrm{mg} \mathrm{Chl} a^{-1}$. Weighing these estimates to the spectral distribution of in situ light $\left(\bar{a}_{\text {phy }}^{*}\right)$ increased values by approximately $25 \%$. No clear diurnal trend was observed in $\bar{a}_{\text {phy }}^{*}$.

The use of HPLC-derived absorption spectra allowed us to examine the contribution of photosynthetic and photoprotective pigments to total light absorption. The Chl $a$-specific absorption coefficient of photosynthetic pigments $\left(\hat{a}_{\mathrm{psp}}^{*}\right)$ ranged from 0.009 to $0.011 \mathrm{~m}^{2} \mathrm{mg} \mathrm{Chl} a^{-1}$, accounting for approximately $75 \%$ of total phytoplankton absorption. By comparison, Chl $a$-specific absorption coefficients for photoprotective pigments, $\hat{a}_{\mathrm{ppc}}^{*}$, were lower (approximately $25 \%$ of total absorption), ranging from 0.0024 to $0.0046 \mathrm{~m}^{2} \mathrm{mg} \mathrm{Chl} a^{-1}$. Both $\hat{a}_{\mathrm{psp}}^{*}$ and $\hat{a}_{\mathrm{ppc}}^{*}$ increased by approximately $20 \%$ when weighted to in situ light $\left(\bar{a}_{\mathrm{psp}}^{*}\right.$ and $\left.\bar{a}_{\mathrm{ppc}}^{*}\right)$. We observed diurnal variability in the relative contribution of these two pigment classes to total absorption, with the relative contribution of photoprotective carotenoids increasing during daylight hours (Fig. 3b).

In addition to the observed changes in pigment ratios, we observed a notable diel cycle in the functional absorption cross section, $\sigma_{\text {PSII-IS }}^{\prime}$, and non-photochemical quenching, NPQNSV, derived for in situ light intensities (Table 2, Fig. 3c, d). Diurnal variability in these two parameters reflects regulation in the transfer of absorbed energy to RCII. The functional absorption cross section exhibited a rapid decline following the onset of daylight, reaching minimum values at noon before increasing back to night-time maxima (Fig. 3c). NPQNSV showed the opposite trend, with maximum values observed during midday, coincident with the minimum in $\sigma_{\text {PSII-IS }}^{\prime}$ (Fig. 3d). The strong inverse correlation (Pearson's 
Table 2. Light absorption characteristics and PSII photo-physiology (process 1 in Fig. 1) for the $48 \mathrm{~h}$ diurnal cycle at OCE17. Surface PAR (400-700 nm, $\mu$ mol quanta $\mathrm{m}^{-2} \mathrm{~s}^{-1}$ ) during each sampling point. Chlorophyll $a$-specific absorption coefficients for phytoplankton $\left(\bar{a}_{\mathrm{phy}}^{*}, \mathrm{~m}^{2} \mathrm{mg} \mathrm{Chl} a^{-1}\right)$ and photosynthetic pigment $\left(\bar{a}_{\mathrm{psp}}^{*}, \mathrm{~m}^{2} \mathrm{mg} \mathrm{Chl} a^{-1}\right)$, estimated using the HPLC pigment reconstruction approach and weighted to the spectral quality of in situ light. The functional absorption cross section of PSII, derived for the dark-regulated state $\left(\sigma_{\mathrm{PSII}}-\mathrm{IS}\right.$, $\AA^{2} \mathrm{RCII}^{-1}$ ) and specific to in situ light quantity at each sampling point ( $\left.\sigma_{\text {PSII-IS }}^{\prime}, \AA^{2} \mathrm{RCII}^{-1}\right)$, both corrected to the spectral quality of in situ light. Estimates of the photosynthetic unit size of PSII $\left(1 / n_{\mathrm{PSII}}, \operatorname{molChl} a\right.$ mol RCII $\left.{ }^{-1}\right) . F_{v} / F_{m}$, the maximum quantum efficiency of charge separation in RCII. $F_{q}^{\prime} / F_{v}^{\prime}(500)$, an estimate of the fraction of "open" reaction centres ( $Q_{A}$ oxidized) at a reference irradiance of $500 \mu \mathrm{mol}$ quanta $\mathrm{m}^{-2} \mathrm{~s}^{-1}$. NPQNSV, normalized Stern-Volmer quenching derived for in situ light intensity at the time and depth of sampling. NPQNSV, normalized Stern-Volmer quenching derived at a reference irradiance of $500 \mu \mathrm{mol}$ quanta $\mathrm{m}^{-2} \mathrm{~s}^{-1}$. See methods section and table 1 for details on derivation of these parameters.

\begin{tabular}{lrrrrrrrrrr}
\hline Local time & Surface PAR & $\bar{a}_{\text {phy }}^{*}$ & $\bar{a}_{\mathrm{pSp}}^{*}$ & $\sigma_{\text {PSII-IS }}$ & $\sigma_{\text {PSII-IS }}^{\prime}$ & $1 / n_{\text {PSII }}$ & $F_{\mathrm{v}} / F_{\mathrm{m}}$ & $F_{\mathrm{q}}^{\prime} / F_{\mathrm{v}}^{\prime}(500)$ & $\mathrm{NPQ}_{\mathrm{NSV}}$ & $\mathrm{NPQ}_{\mathrm{NSV}}(500)$ \\
\hline $04: 00$ & 0 & 0.018 & 0.013 & 326 & 326 & 380 & 0.59 & 0.29 & 0.71 & 1.53 \\
$06: 00$ & 0 & & & 303 & 303 & & 0.57 & 0.41 & 0.76 & 1.60 \\
$08: 00$ & 175 & 0.017 & 0.014 & 300 & 263 & 313 & 0.57 & 0.45 & 0.82 & 1.74 \\
$10: 00$ & 188 & & & 317 & 279 & & 0.54 & 0.52 & 0.92 & 1.82 \\
$12: 00$ & 1054 & 0.019 & 0.01 & 325 & 223 & 446 & 0.49 & 0.57 & 1.5 & 1.89 \\
$14: 00$ & 1033 & & & 326 & 235 & & 0.43 & 0.64 & 1.89 & 2.47 \\
$16: 00$ & 1125 & 0.021 & 0.012 & 318 & 228 & 399 & 0.4 & 0.67 & 2.2 & 2.77 \\
$18: 00$ & 1163 & & & 316 & 221 & & 0.48 & 0.5 & 1.83 & 2.22 \\
$20: 00$ & 24 & 0.019 & 0.014 & 314 & 297 & 337 & 0.51 & 0.35 & 0.98 & 2.26 \\
$22: 00$ & 0 & & & 297 & 297 & & 0.52 & 0.3 & 0.93 & 2.39 \\
$00: 00$ & 0 & 0.018 & 0.013 & 303 & 303 & 338 & 0.52 & 0.3 & 0.93 & 2.36 \\
$02: 00$ & 0 & & & 306 & 306 & & 0.52 & 0.36 & 0.92 & 2.35 \\
$04: 00$ & 0 & 0.019 & 0.013 & 298 & 298 & 330 & 0.51 & 0.34 & 0.94 & 2.16 \\
$06: 00$ & 0 & & & 290 & 290 & & 0.5 & 0.39 & 1.02 & 2.29 \\
$08: 00$ & 270 & 0.017 & 0.013 & & & 338 & & & & \\
$10: 00$ & 1107 & & & 322 & 216 & & 0.47 & 0.67 & 1.73 & 2.19 \\
$12: 00$ & 1255 & 0.022 & 0.012 & 271 & 216 & 341 & 0.43 & 0.65 & 2.26 & 2.57 \\
$14: 00$ & 1431 & & & 271 & 195 & & 0.35 & 0.73 & 2.63 & 2.87 \\
$16: 00$ & 1085 & 0.019 & 0.013 & 302 & 221 & 348 & 0.38 & 0.73 & 2.18 & 2.87 \\
$18: 00$ & 347 & & & 314 & 292 & & 0.45 & 0.58 & 1.56 & 2.69 \\
$20: 00$ & 24 & 0.015 & 0.011 & 272 & 270 & 382 & 0.41 & 0.48 & 1.55 & 2.23 \\
$22: 00$ & 0 & & & & & & & & & \\
$00: 00$ & 0 & 0.015 & 0.014 & 268 & 268 & 284 & 0.54 & 0.27 & 0.86 & 2.06 \\
$02: 00$ & 0 & & & 277 & 277 & & 0.5 & 0.35 & 0.99 & 2.68 \\
\hline
\end{tabular}

$\rho=0.87, p<0.001, n=22$ ) between $\sigma_{\mathrm{PSII}-\mathrm{IS}}^{\prime}$ and NPQ $\mathrm{NSV}$ is expected and demonstrates that NPQNSV is primarily attributable to thermal dissipation of excess excitation energy in the antenna (e.g. Xu et al., 2017).

Diurnal cycles in photoprotective pigment content and energy transfer within the pigment antenna (Fig. 3b-d) act to prevent excess excitation energy from reaching RCII, thus minimizing potential photodamage (Fig. 1, process 1). Excitation energy at the level of RCII can also be reduced by increasing the rate of charge separation and downstream electron transport (Fig. 1, process 2 and 3). Figure 3e shows the diel pattern in $F_{q}^{\prime} / F_{v}^{\prime}(500)$, a variable which estimates the fraction of open RCII at a reference irradiance level of $500 \mu \mathrm{mol}$ quanta $\mathrm{m}^{-2} \mathrm{~s}^{-1}$. Values of $F_{q}^{\prime} / F_{v}^{\prime}(500)$ clearly followed the availability of light, indicating an increased ability to maximize the number of RCII in the open state $\left(Q_{A}\right.$ oxidized) during high-light periods. The clear diurnal cycle in $F_{q}^{\prime} / F_{v}^{\prime}(500)$ illustrates diurnal regulation of reactions down- stream of light absorption and excitation energy transfer to RCII. This, in turn, implicates the upregulation of reactions downstream of PSII (Fig. 1, process 3).

Parameters derived from ETR $\mathrm{RCII}_{\text {and }}{ }^{14} \mathrm{C}$-uptake lightresponse curves are shown in Table 3 and Fig. 4. ETR $_{\mathrm{RCII}}-P_{\max }$ ranged from 220 to 884 with a mean of $479 \mathrm{~mol} \mathrm{e}^{-} \mathrm{mol} \mathrm{RCII}^{-1} \mathrm{~s}^{-1}$. These values are in good agreement with values from previous studies (e.g. Hancke et al., 2015; Zhu et al., 2017) and fall below the theoretical maximum of $1000 \mathrm{~mol} \mathrm{e}^{-} \mathrm{mol} \mathrm{RCII}^{-1} \mathrm{~s}^{-1}$ for linear electron transport (Falkowski and Raven, 1997). Values of $\mathrm{ETR}_{\mathrm{RCII}}-\alpha$ ranged from 1.24 to 2.42 , with a mean of $1.76 \mathrm{~mol} \mathrm{e}^{-} \mathrm{mol} \mathrm{RCII}^{-1} \mathrm{~s}^{-1}$ ( $\mu$ mol quanta $\left.\mathrm{m}^{-2} \mathrm{~s}^{-1}\right)^{-1}$. The $E_{k}$ of $\mathrm{ETR}_{\mathrm{RCII}}$ varied from 160 to 410 , with a mean of $262 \mu$ mol quanta $\mathrm{m}^{-2} \mathrm{~s}^{-1}$.

Clear diurnal periodicity in $P_{\max }, \alpha$ and $E_{k}$ of ETR $\mathrm{RCII}$ was observed in response to diurnal changes in light availability (Fig. 4c, e, g), with all three parameters showing max- 
Table 3. Light-response curve fit parameters for rates of charge separation in RCII (ETR $\mathrm{RCII})$ and ${ }^{14} \mathrm{C}$ uptake for the $48 \mathrm{~h}$ diurnal cycle at OCE17. Units of ETR $\mathrm{RCII}_{\text {are mol }} \mathrm{molRCII}^{-1} \mathrm{~s}^{-1}$ and units of ${ }^{14} \mathrm{C}$ uptake are $\mathrm{g} \mathrm{Cg} \mathrm{Chl} a^{-1} \mathrm{~h}^{-1}$. $P_{\text {max }}$ is the maximum rate at light saturation, $\alpha$ is light efficiency of each rate under light limitation and $E_{k}$ is the light saturation parameter $\left(\mu \mathrm{mol}\right.$ quanta $\mathrm{m}^{-2} \mathrm{~s}^{-1}$ ). The errors given are the $95 \%$ confidence intervals for the fit parameter $P_{\max }$ and $\alpha$, as well as the propagated error for $E_{k}$. In situ (IS) represents realized rates derived for in situ light intensities for the time and depth of sampling. $\Phi_{\mathrm{e}, \mathrm{C}}$ is the electron requirement for carbon fixation $\left(\mathrm{mol} \mathrm{e}^{-} \mathrm{mol} \mathrm{C}^{-1}\right)$, and $\Phi_{\mathrm{C}}$ is the quantum efficiency of carbon fixation (mol $\mathrm{Cmol} \mathrm{photon} \mathrm{absorbed}{ }^{-1}$ ). The minimum value of $\Phi_{\mathrm{e}, \mathrm{C}}$ and maximum value of $\Phi_{\mathrm{C}}$ at each time point are theoretical values describing the acclimation state of the entire photosynthetic process. In situ (IS) values are realized values of $\Phi_{\mathrm{e}, \mathrm{C}}$ and $\Phi_{\mathrm{C}}$ derived for in situ light intensities at the time and depth of sampling.

\begin{tabular}{|c|c|c|c|c|c|c|c|c|c|c|c|c|}
\hline \multirow[t]{2}{*}{ Local time } & \multicolumn{4}{|c|}{$\mathrm{ETR}_{\mathrm{RCII}}$} & \multicolumn{4}{|c|}{${ }^{14} \mathrm{C}$ uptake } & \multicolumn{2}{|c|}{$\Phi_{\mathrm{e}, \mathrm{C}}$} & \multicolumn{2}{|c|}{$\Phi_{\mathrm{C}}$} \\
\hline & $P_{\max }$ & $\alpha$ & $E_{k}$ & IS & $P_{\max }$ & $\alpha$ & $E_{k}$ & IS & $\min$ & IS & $\max$ & IS \\
\hline 04:00 & $295 \pm 8$ & $1.49 \pm 0.01$ & $198 \pm 13$ & 0 & $1.7 \pm 1.1$ & $0.06 \pm 0.14$ & $29 \pm 70$ & 0.0 & $3 \pm 8$ & 0 & 0.08 & \\
\hline 06:00 & $412 \pm 13$ & $1.62 \pm 0.01$ & $253 \pm 16$ & 0 & & & & & & & & \\
\hline 08:00 & $426 \pm 17$ & $1.79 \pm 0.14$ & $238 \pm 21$ & 120 & $2.2 \pm 0.6$ & $0.08 \pm 0.09$ & $27 \pm 31$ & 2.0 & $4 \pm 4$ & 9 & 0.11 & 0.03 \\
\hline 10:00 & $532 \pm 12$ & $1.94 \pm 0.07$ & $274 \pm 12$ & 142 & & & & & & & & \\
\hline 12:00 & $623 \pm 20$ & $2.26 \pm 0.13$ & $276 \pm 18$ & 512 & $3.0 \pm 0.3$ & $0.08 \pm 0.03$ & $39 \pm 16$ & 3.0 & $3 \pm 1$ & 19 & 0.09 & 0.01 \\
\hline $14: 00$ & $725 \pm 15$ & $2.42 \pm 0.08$ & $299 \pm 11$ & 572 & & & & & & & & \\
\hline $16: 00$ & $729 \pm 16$ & $2.35 \pm 0.08$ & $311 \pm 12$ & 585 & $3.5 \pm 0.4$ & $0.06 \pm 0.02$ & $62 \pm 20$ & 3.5 & $5 \pm 1$ & 20 & 0.06 & 0.01 \\
\hline 18:00 & $489 \pm 12$ & $2.07 \pm 0.11$ & $237 \pm 13$ & 435 & & & & & & & & \\
\hline 20:00 & $340 \pm 10$ & $1.66 \pm 0.09$ & $204 \pm 14$ & 18 & $2.5 \pm 0.3$ & $0.06 \pm 0.03$ & $38 \pm 18$ & 0.6 & $4 \pm 2$ & 4 & 0.08 & 0.07 \\
\hline 22:00 & $237 \pm 13$ & $1.47 \pm 0.19$ & $162 \pm 24$ & 0 & & & & & & & & \\
\hline 00:00 & $261 \pm 13$ & $1.29 \pm 0.14$ & $203 \pm 24$ & 0 & $1.2 \pm 0.1$ & $0.04 \pm 0.02$ & $29 \pm 13$ & 0.0 & $5 \pm 2$ & 0 & 0.05 & \\
\hline 02:00 & $331 \pm 23$ & $1.24 \pm 0.15$ & $266 \pm 38$ & 0 & & & & & & & & \\
\hline 04:00 & $321 \pm 13$ & $1.37 \pm 0.11$ & $235 \pm 20$ & 0 & $1.7 \pm 0.2$ & $0.08 \pm 0.03$ & $23 \pm 10$ & 0.0 & $3 \pm 1$ & 0 & 0.09 & \\
\hline 06:00 & $345 \pm 29$ & $1.48 \pm 0.24$ & $234 \pm 42$ & 0 & & & & & & & & \\
\hline 08:00 & & & & & $2.0 \pm 0.4$ & $0.06 \pm 0.05$ & $36 \pm 29$ & 1.9 & & & 0.08 & 0.02 \\
\hline 10:00 & $807 \pm 35$ & $2.14 \pm 0.12$ & $378 \pm 27$ & 591 & & & & & & & & \\
\hline $12: 00$ & $602 \pm 21$ & $1.75 \pm 0.09$ & $344 \pm 21$ & 485 & $3.2 \pm 0.4$ & $0.06 \pm 0.03$ & $51 \pm 23$ & 3.2 & $4 \pm 2$ & 21 & 0.07 & 0.01 \\
\hline 14:00 & $784 \pm 23$ & $2.14 \pm 0.09$ & $366 \pm 18$ & 649 & & & & & & & & \\
\hline $16: 00$ & $884 \pm 42$ & $2.16 \pm 0.13$ & $410 \pm 31$ & 615 & $3.0 \pm 0.3$ & $0.04 \pm 0.01$ & $68 \pm 20$ & 3.0 & $7 \pm 2$ & 28 & 0.05 & 0.01 \\
\hline 18:00 & $579 \pm 14$ & $2.02 \pm 0.08$ & $286 \pm 13$ & 243 & & & & & & & & \\
\hline $20: 00$ & $305 \pm 15$ & $1.39 \pm 0.14$ & $219 \pm 24$ & 15 & $2.0 \pm 0.2$ & $0.03 \pm 0.01$ & $72 \pm 22$ & 0.3 & $6 \pm 2$ & 7 & 0.04 & 0.03 \\
\hline $22: 00$ & & & & & & & & & & & & \\
\hline 00:00 & $220 \pm 8$ & $1.37 \pm 0.12$ & $160 \pm 15$ & 0 & $1.2 \pm 0.6$ & $0.05 \pm 0.08$ & $27 \pm 52$ & 0.0 & $5 \pm 9$ & 0 & 0.07 & \\
\hline 02:00 & $284 \pm 21$ & $1.30 \pm 0.19$ & $220 \pm 36$ & 0 & & & & & & & & \\
\hline
\end{tabular}

imum values during high-irradiance midday periods. In situ light availability at the time and depth of sampling exceeded the $E_{k}$ for most of the day, meaning that $\mathrm{ETR}_{\mathrm{RCII}}$ at $5 \mathrm{~m}$ depth was not light-limited during a substantial portion of the day (Fig. 4a, g; note different scales on the panels).

Maximum rates of ${ }^{14} \mathrm{C}$ uptake ranged from 1.17 to 3.54

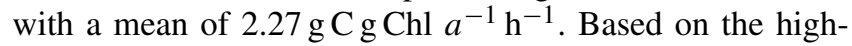
nutrient and biomass conditions at OCE17, we assume that phytoplankton growth rate was relatively high, such that these $2 \mathrm{~h}{ }^{14} \mathrm{C}$-uptake experiments estimated a rate close to gross primary productivity (e.g. Halsey and Jones, 2015; Milligan et al., 2015). Values of the light-dependent increase in ${ }^{14} \mathrm{C}$ uptake $(\alpha)$ ranged from 0.03 to $0.08 \mathrm{~g} \mathrm{Cg} \mathrm{Chl} a^{-1} \mathrm{~h}^{-1}$ $\left(\mu \mathrm{mol}\right.$ quanta $\mathrm{m}^{-2} \mathrm{~s}^{-1}$ ), while the light-saturation parameter $E_{k}$ varied between 23 and $72 \mu$ mol quanta $\mathrm{m}^{-2} \mathrm{~s}^{-1}$ (Table 3, Fig. 4d, f, h). Clear diurnal trends were apparent in the $P_{\max }$ of ${ }^{14} \mathrm{C}$ uptake (Fig. $4 \mathrm{~d}$ ); however, this trend was not observed for $\alpha$, which decreased throughout each day (Fig. 4f). Values

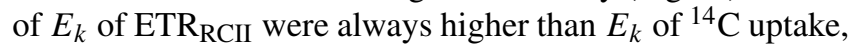

meaning that ${ }^{14} \mathrm{C}$ uptake saturated at light intensities at which

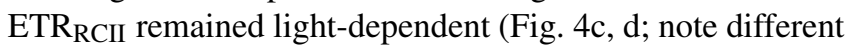
scales on the panels).

An increase in the electron requirement for carbon fixation $\left(\Phi_{\mathrm{e}, \mathrm{C}}, \mathrm{mol} \mathrm{e}^{-} \mathrm{mol} \mathrm{C}^{-1}\right)$ is expected when ${ }^{14} \mathrm{C}$ uptake, but not ETR, is light-saturated. Under such conditions, additional electrons from charge separation in RCII must be used for processes other than ${ }^{14} \mathrm{C}$ uptake (Fig. 1). As expected, values of $\Phi_{\mathrm{e}, \mathrm{C}}$ derived for in situ light availability (Table 3, Fig. 5b) showed a clear diurnal trend, closely following the diurnal change in light availability. Increased decoupling of ${ }^{14} \mathrm{C}$ uptake and ETR $\mathrm{RCII}_{\mathrm{I}}$ under excess light (e.g. Corno et al., 2006; Fujiki et al., 2007; Schuback et al., 2017; Zhu et al., 2017) can be attributed to an upregulation of alternative electron sinks necessary to alleviate backpressure along the electron transport chain, once carbon fixation is light-saturated (e.g. Niyogi, 2000).

Figure 5 also shows diurnal trends in the quantum efficiency of carbon fixation, $\Phi_{C}$. This variable is influenced by 

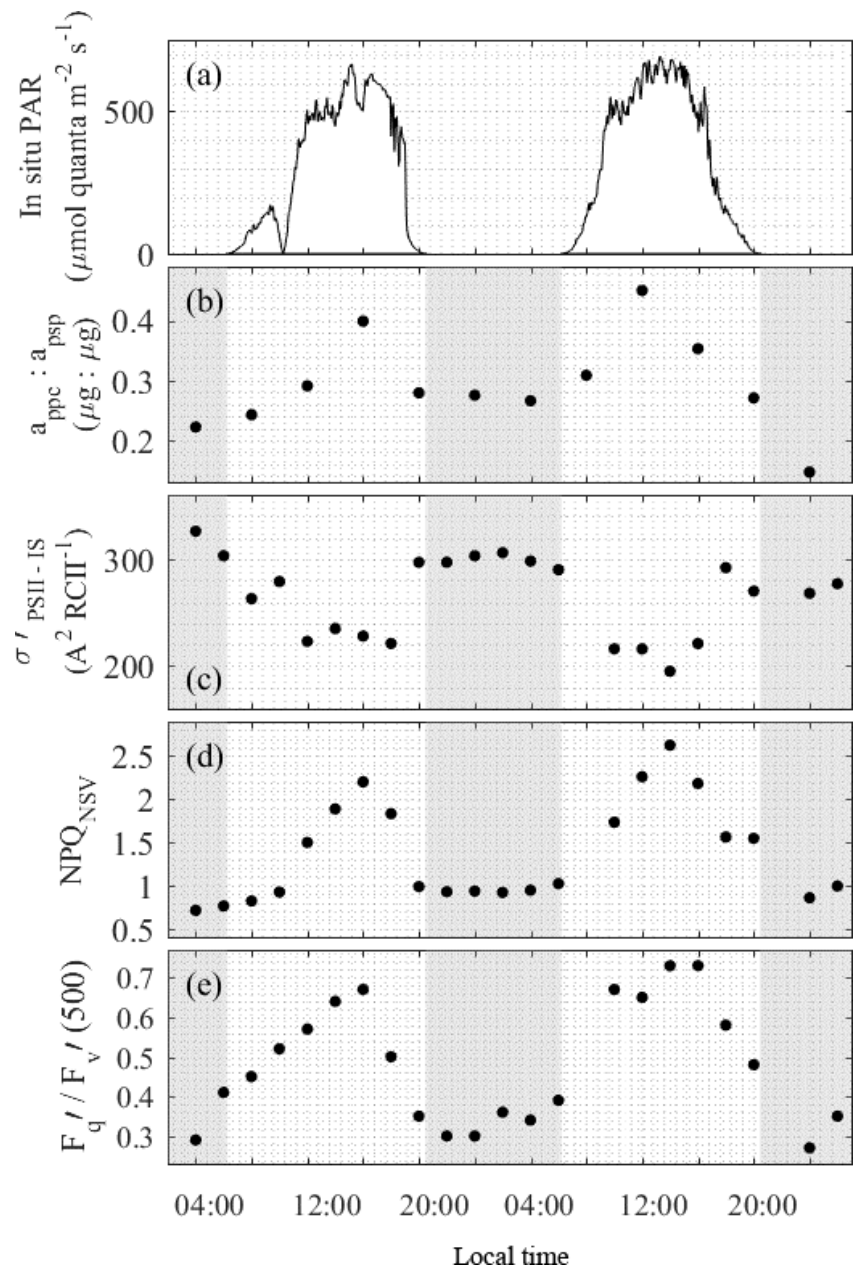

Figure 3. Diurnal variability in light absorption and energy transfer in the light-harvesting antenna of PSII (Fig. 1, process 1) at the OCE17 site. (a) PAR estimated for $5 \mathrm{~m}$ sampling depth. (b) Ratio of absorption by photoprotective carotenoids $\left(\bar{a}_{\mathrm{ppc}}^{*}\right)$ to absorption by photosynthetic pigment $\left(\bar{a}_{\mathrm{psp}}^{*}\right)$, where both values are derived from spectral reconstruction of HPLC pigment data. (b) Values of $\sigma_{\text {PSII-IS }}^{\prime}$, spectrally corrected to in situ spectral light quality, derived from FRRF light-response curves at light levels corresponding to

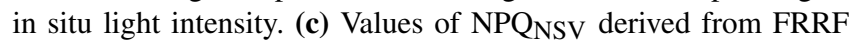
light-response curves at light levels corresponding to in situ light intensity at the time and depth of sampling. (d) Values of $F_{q}^{\prime} / F_{v}^{\prime}$ derived from FRRF light-response curves at a reference background irradiance of $500 \mu \mathrm{mol}$ quanta $\mathrm{m}^{-2} \mathrm{~s}^{-1}$.

the decoupling of electron transport and carbon fixation (i.e. $\Phi_{e, C}$, Fig. 1) and additionally by variations in the fraction of absorbed light energy allocated to photochemistry (Fig. 1). Both the decoupling of electron transport from carbon fixation $\left(\Phi_{\mathrm{e}, \mathrm{C}}\right.$, Fig. 5a) and the quantum efficiency of carbon fixation $\left(\Phi_{\mathrm{C}}\right.$, Fig. $\left.5 \mathrm{~b}\right)$ showed a clear dependence on diurnal variation in light availability.

\subsection{Comparison between OCE17 and OSP14}

The light-dependent photosynthetic response is strongly modified by environmental factors including temperature, nutrient availability, average light intensity and light history (e.g. Sakshaug et al., 1997). Micronutrient limitation, most notably iron, has also been shown to exert a significant effect on light-dependent photosynthetic responses (Greene et al., 1991, 1992; Roncel et al., 2016; Schuback et al., 2015). Here, we examine potential iron-dependent effects by comparing absolute values and diurnal periodicity of components of the photosynthetic process between the high-productivity coastal waters of OCE17 and the iron-limited NE subarctic Pacific (OSP14, Schuback et al., 2016). Such a comparison is necessarily complicated by uncontrolled variability in a number of environmental and ecological factors, in addition to the iron status of resident phytoplankton assemblages. Nonetheless, we argue below that a clear signature of iron-limited physiology emerges from this comparison.

\subsubsection{Comparison between environmental and ecological conditions between sampling sites}

Table 4 summarizes hydrographic and biological properties of the two study sites. Temperature and salinity within the upper mixed layer were similar in both environments $\left(11.5^{\circ} \mathrm{C}\right.$ and 32.6 PSU at OCE17, $10.4{ }^{\circ} \mathrm{C}$ and 32.4 PSU at OSP14), and the sites had well-defined mixed layers, with a depth of $\sim 11 \mathrm{~m}$ at OCE17 and $\sim 33 \mathrm{~m}$ at OSP14. Excess macronutrient concentrations were observed within the mixed layer of both stations (Table 4). However, micronutrients, most notably iron, were likely limiting phytoplankton growth at OSP14, thus accounting for the significantly lower [Chl $a$ ] at this site $\left(0.18 \mu \mathrm{g} \mathrm{L}-1\right.$, as compared to $1.04 \mu \mathrm{g} \mathrm{L}^{-1}$ at OCE17, Table 4).

As expected, iron limitation also affected the phytoplankton community structure. We derived an estimate of phytoplankton community structure using pigment-based size classes (Claustre, 1994; Uitz et al., 2006; Vidussi et al., 2001). These estimates revealed that OCE17 was dominated by microphytoplakton $(>20 \mu \mathrm{m}, \sim 67 \%$ ), with $\sim 33 \%$ of the phytoplankton assemblage attributable to the picophytoplankton size class $(0.2-2 \mu \mathrm{m})$. Based on the high concentration of the pigment fucoxanthin, we assume that diatoms dominated the microphytoplankton size class in this region. Characteristic pigments for the nanophytoplankton size class (2-20 $\mu \mathrm{m}$, e.g. cryptophytes, chromophytes and nanoflagellates) were present in very low concentrations at the OCE17 site, indicating a negligible contribution of this size to the phytoplankton assemblage. In contrast to the OCE17 site, the phytoplankton assemblage at OSP14 was dominated by picophytoplankton $(\sim 46 \%)$, with an estimated contribution of $\sim 29 \%$ and $\sim 25 \%$ for the nano and micro size classes, respectively. The high concentration of zeaxanthin found at OSP14 suggests a high proportion of cyanobacteria in 


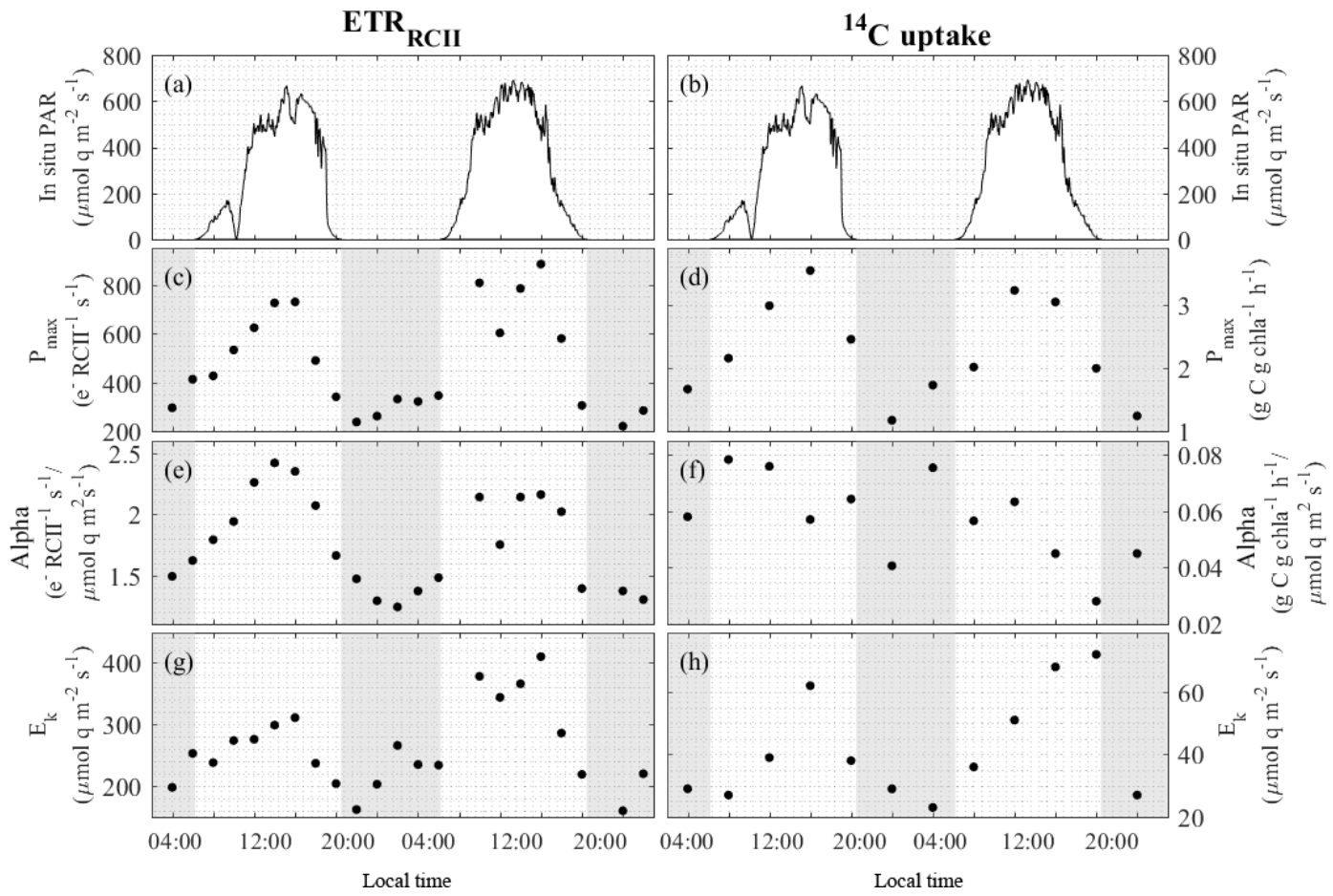

Figure 4. Diurnal variability in light-response curve fit parameters for $\mathrm{ETR}_{\mathrm{RCII}}$ (left) and ${ }^{14} \mathrm{C}$ uptake (right) for the OCE17 site.(a) and (b) show PAR at $5 \mathrm{~m}$ sampling depths. (c) and (d) show the maximum light-saturated capacity $P_{\max }$ of each rate. (e) and (f) show the light efficiency of each rate under light limitation, $\alpha .(\mathbf{g})$ and (h) show the light saturation parameter $E_{k}$ of each rate. Note different scales on (a), (b), (g) and (h).

Table 4. Comparison of environmental conditions at the offshore, iron-limited site OSP14 (17 June 2014) and the coastal, nutrient-rich site OCE17 (21 August 2017). See text for details on derivation of each variable.

\begin{tabular}{|c|c|c|c|}
\hline & & OSP14 & OCE17 \\
\hline Lat & ${ }^{\circ} \mathrm{N}$ & 50.1 & 144.9 \\
\hline Long & ${ }^{\circ} \mathrm{W}$ & 44.3 & 124.4 \\
\hline sunrise (PDT) & hh:mm & $06: 27$ & $06: 26$ \\
\hline sunset (PDT) & hh:mm & $22: 49$ & $20: 12$ \\
\hline day length & hh:mm & $16: 22$ & $13: 46$ \\
\hline$k_{d}$ & $m^{-1}$ & 0.07 & 0.16 \\
\hline$E_{0}$ & mol quanta $\mathrm{m}^{-2} \mathrm{~d}^{-1}$ & 31.94 & 36.21 \\
\hline$E_{\mathrm{mL}}$ mean & mol quanta $\mathrm{m}^{-2} \mathrm{~d}^{-1}$ & 12.45 & 17.03 \\
\hline$E_{\mathrm{mL}}$ median & mol quanta $\mathrm{m}^{-2} \mathrm{~d}^{-2}$ & 10.1 & 15.0 \\
\hline$E_{5 \mathrm{~m}}$ & mol quanta $\mathrm{m}^{-2} \mathrm{~d}^{-1}$ & 21.4 & 16.24 \\
\hline$E_{5 \mathrm{~m}}$ mean & $\mu \mathrm{mol}$ quanta $\mathrm{m}^{-2} \mathrm{~s}^{-1}$ & 281 & 313 \\
\hline$E_{5 \mathrm{~m}} \max$ & $\mu \mathrm{mol}$ quanta $\mathrm{m}^{-2} \mathrm{~s}^{-1}$ & 802 & 661 \\
\hline temp & ${ }^{\circ} \mathrm{C}$ & 10.4 & 11.5 \\
\hline salinity & PSU & 32.4 & 32.6 \\
\hline MLD & $\mathrm{m}$ & 33 & 11 \\
\hline$\left[\mathrm{NO}_{3}+\mathrm{NO}_{2}\right]$ & $\mu \mathrm{M}$ & 9.1 & 8.6 \\
\hline$[\mathrm{P}]$ & $\mu \mathrm{M}$ & 0.98 & 0.8 \\
\hline$[\mathrm{Si}]$ & $\mu \mathrm{M}$ & 14.5 & 9.8 \\
\hline$[$ TChl $a]$ & $\mu g \mathrm{~L}^{-1}$ & 0.18 & 1.04 \\
\hline f_micro & $\%$ & 67 & 25 \\
\hline f_nano & $\%$ & 0 & 29 \\
\hline f_pico & $\%$ & 33 & 46 \\
\hline
\end{tabular}




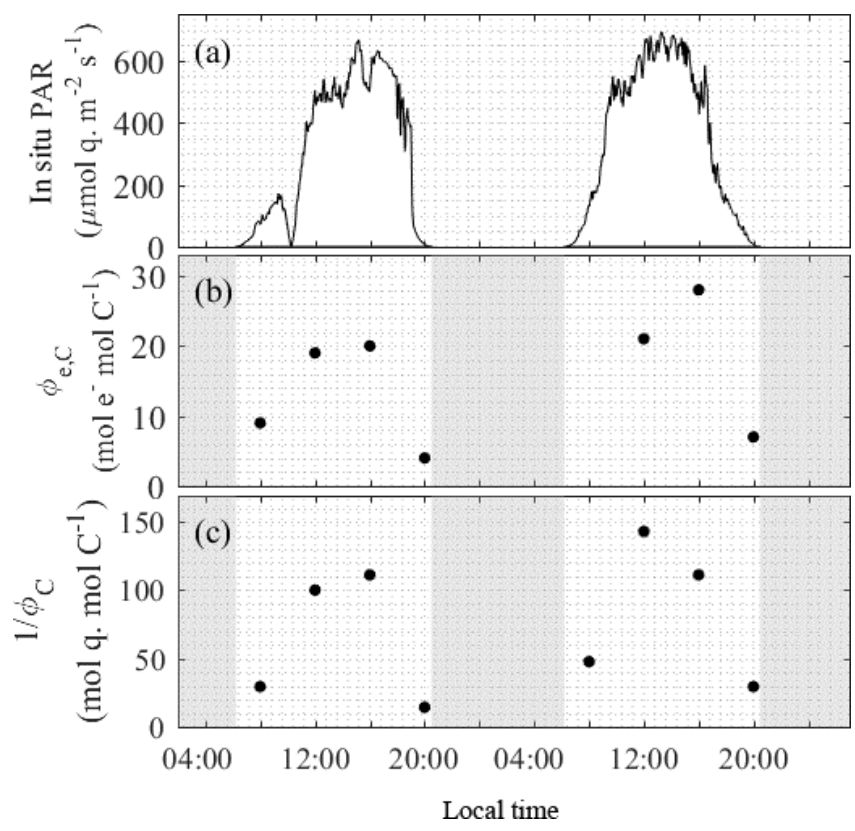

Figure 5. The realized electron and photon requirements of carbon fixation over a $48 \mathrm{~h}$ diurnal cycle at the OCE17 site. Values of $\Phi_{\mathrm{e}, \mathrm{C}}$ and $1 / \Phi_{C}$ correspond to light conditions at the time and depth of sampling. Note that we present the photon requirement for carbon fixation, $1 / \Phi_{\mathrm{C}}$, instead of the photon efficiency of carbon fixation $\left(\Phi_{\mathrm{C}}\right)$, to facilitate better comparability with $\Phi_{\mathrm{e}, \mathrm{C}}$.

the smallest size class, while the relatively high values of $19^{\prime} \mathrm{BF}$ and $19^{\prime} \mathrm{HF}$ are characteristic for prymnesiophytes and pelagophytes. A summary of the HPLC pigment data is provided in Supplement S3.

Daylight hours at OSP14 were slightly longer than at OCE17 ( $\sim 16$ vs. $14 \mathrm{~h}$, respectively), while daily integrated incident photon dose $\left(E_{0}\right)$ was higher at OCE17 (36.21 vs. 31.94 mol quanta $\mathrm{m}^{-2}$ ). However, given the greater water column light extinction coefficient $\left(k_{d}, \mathrm{~m}^{-1}\right)$ at the OCE17 site $\left(1.6 \mathrm{~m}^{-1}\right.$; vs. $\left.0.7 \mathrm{~m}^{-1}\right)$, light availability calculated for the $5 \mathrm{~m}$ sampling depth was similar for the two sites (Table 4 , Fig. 6d). In our analysis, we used instantaneous in situ light intensities to derive photo-physiological parameters and ${ }^{14} \mathrm{C}$ uptake rates from light-response curves. This approach is justified for a direct comparison of rates and diurnal patterns at a fixed depth. We note, however, that the deeper mixed layer at OSP14 likely affected the photo-acclimation status of the phytoplankton assemblage, as a result of stronger variability in light, as well as lower mean and median mixed layer irradiance levels.

\subsubsection{Effects of iron limitation on photo-physiology and diurnal regulation of photosynthesis}

The photosynthetic electron transport chain has a high requirement for iron (Raven et al., 1999; Yruela, 2013), and iron limitation has been shown to exert a significant ef- fect on the abundance and stoichiometry of its components (e.g. Davey and Geider, 2001; Ivanov et al., 2000; Strzepek and Harrison, 2004). Our data also clearly demonstrate this effect. The mean Chl $a$-specific phytoplankton absorption coefficient, $\bar{a}_{\text {phy }}^{*}\left(\mathrm{~m}^{2} \mathrm{mgChl} a^{-1}\right)$, was 1.9-fold higher at OSP14 (Fig. 6a). This result can be explained by the smaller cell size and lower cellular [Chl $a$ ] expected in iron-limited phytoplankton, both of which reduce the packaging effect (Bricaud et al., 1995; Morel and Bricaud, 1981). We also observed a greater contribution of photoprotective pigments to light absorption at OSP14 (31\%) relative to OCE17 (22\%) (Fig. 6a). As discussed below, this result can be explained by the increased requirement for photoprotection under ironlimited growth conditions.

We found that the number of (iron-rich) PSII per Chl $a$ $\left(n_{\mathrm{PSII}}\right.$, mol RCII mol Chl $\left.a^{-1}\right)$ at OSP14 was approximately half of that observed at OCE17 (Fig. 6b). To partly compensate for this reduction in RCII, the dark-regulated functional absorption cross section ( $\sigma_{\mathrm{PSII}-\mathrm{IS}}, \AA^{2} \mathrm{RCII}^{-1}$ ) at OSP14 was almost 3 times higher than at OCE17 (Fig. 6c). This physiological response to iron limitation has been frequently observed in previous studies (Boyd et al., 2000; Kolber et al., 1994; Moore et al., 2007; Strzepek et al., 2012; Vassiliev et al., 1995).

Increased light absorption and charge separation per RCII observed at OSP14 creates the potential for oversaturation of the reaction centres and resulting photoinhibition. This, in turn, increases the requirement for active energy dissipation mechanisms. Indeed, we observed strong diurnal adjust-

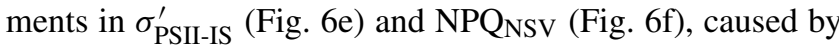
active light-dependent regulation of excitation energy within the pigment antenna. Importantly, the dynamic range of lightregulated $\sigma_{\mathrm{PSII}-\mathrm{IS}}^{\prime}$ and $\mathrm{NPQ}_{\mathrm{NSV}}$ regulation over a diurnal cycle was significantly larger at OSP14 than at OCE17 (3-fold vs. 1.5-fold at OCE17), despite similar light intensities at the two sites (Fig. 6d-f). Our data therefore suggest an increased need for active regulation of energy dissipation in response to daily irradiance cycles in iron-limited waters.

Iron limitation comprises the plasticity of the photosynthetic process and its ability to utilize high light intensities for carbon fixation. However, this does not lead to the reduction in light absorption, as one might expect of a system less capable of processing light energy and more susceptible to damage by excess absorbed light. Rather, we observed an increased capacity for dissipation of excess absorbed energy through enhanced NPQ. Such a regulatory mechanism allows phytoplankton to maximize photosynthesis under low-light conditions, while preventing damage at high irradiances. Our results support previous observations showing high levels of NPQ in a variety of iron-limited phytoplankton in laboratory and field studies (e.g. Alderkamp et al., 2012; Allen et al., 2008; Hoppe et al., 2013; Petrou et al., 2014; Schallenberg et al., 2019; Schuback et al., 2015; Terauchi et al., 2010; Vassiliev et al., 1995). A high NPQ signature may thus hold potential as an optical indicator for phytoplankton physiology 

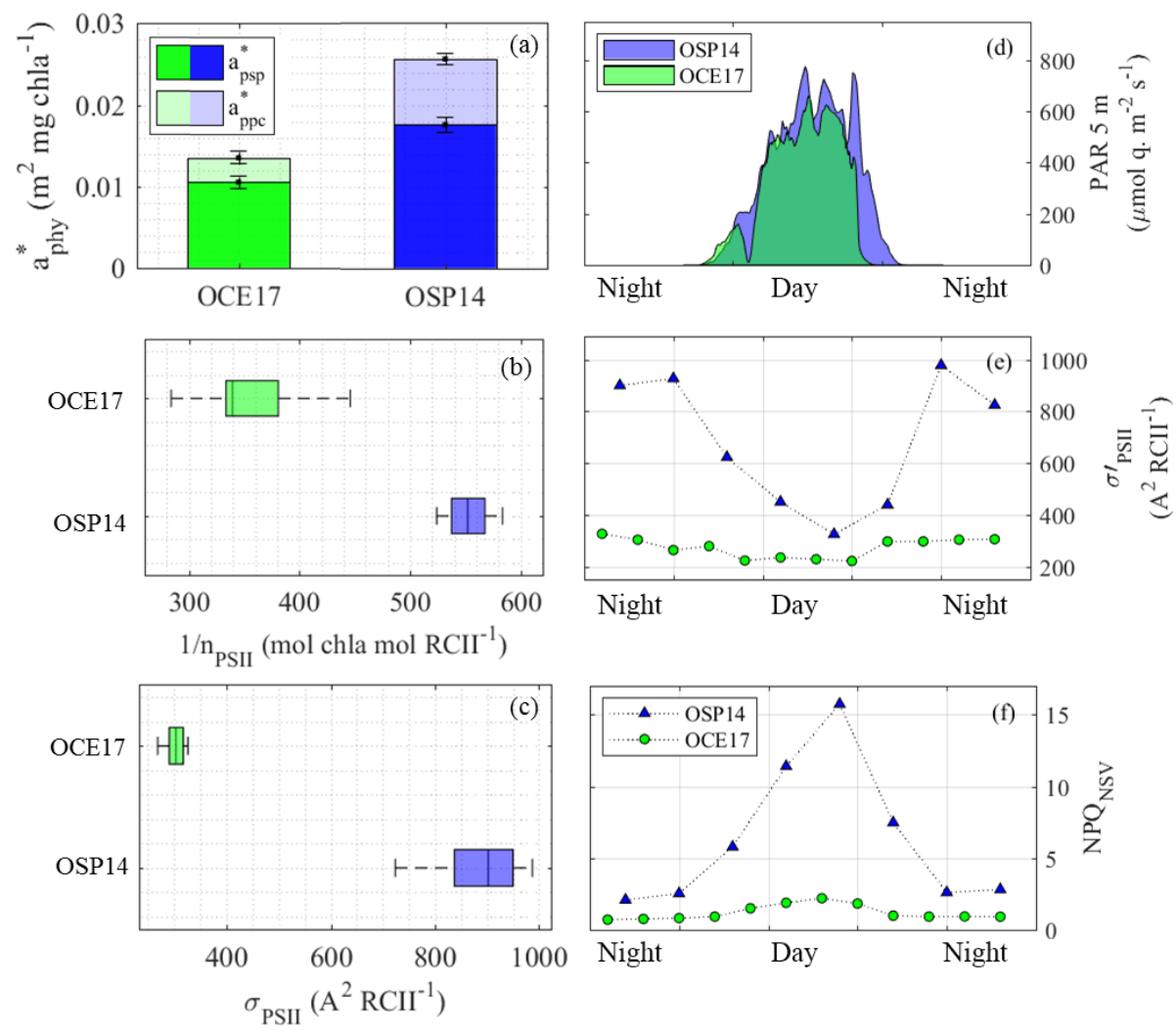

Figure 6. Comparison of light absorption characteristics at the OSP14 and OCE17 sampling sites. (a) The mean (400-700 nm) Chl $a$-specific absorption coefficient of phytoplankton $\left(\hat{a}_{\mathrm{phy}}^{*}, \mathrm{~m}^{2} \mathrm{mg} \mathrm{Chl} a^{-1}\right)$, showing contribution of absorption by photosynthetic pigment $\left(\hat{a}_{\mathrm{psp}}^{*}\right)$ and photoprotective carotenoids $\left(\hat{a}_{\mathrm{ppc}}^{*}\right)$. (b) Photosynthetic unit size of PSII, $1 / n_{\mathrm{PSII}}\left(\mathrm{mol} \mathrm{Chl} a \mathrm{~mol} \mathrm{RCII}^{-1}\right.$ ). (c) The functional absorption cross section of PSII, $\sigma_{\text {PSII }}\left(\AA^{2} \mathrm{RCII}^{-1}\right)$, derived for the dark-regulated state at each time point. In (b) and (c) the central mark in each box is the median, the edges of the box are the 25th and 75th percentiles, and the whiskers extend to the range of all data. No clear diurnal trend in $1 / n_{\text {PSII }}$ or $\sigma_{\text {PSII }}$ was detected at either station. (d) Values of PAR (400-700 nm, $\mu$ mol quanta $\mathrm{m}^{-2} \mathrm{~s}^{-1}$ ) at $5 \mathrm{~m}$ sampling depth. (e) The functional absorption cross section of PSII, $\sigma_{\mathrm{PSII}}^{\prime}\left(\AA^{2} \mathrm{RCII}{ }^{-1}\right)$, measured at the light-regulated state corresponding to in situ light intensity at each time point. (f) Non-photochemical quenching, measured at the light-regulated state corresponding to in situ light intensity at each time point.

and iron-nutrition status in the oceans (Schallenberg et al., 2019).

Further evidence of active regulation of excitation energy at the level of RCII can be seen in the high values and strong light-dependent increase in $\mathrm{ETR}_{\mathrm{RCII}}$ observed at OSP14 (Fig. 7b). The high midday rates of ETR RCII $_{\text {at }}$ OSP14 were not balanced by increased ${ }^{14} \mathrm{C}$ uptake (Fig. 7c) and exceeded the maximum theoretical value for linear electron transport. As described by Schuback et al. $(2015,2016)$, upregulation of alternative electron sinks, cyclic electron transport, and charge recombination may all act to dissipate excess electrons and thereby prevent over-reduction of RCII. These mechanisms are manifested in an increase in ETR $_{R C I I}$ and can account for the diurnal variation in the electron requirement of carbon fixation $\left(\Phi_{\mathrm{e}, \mathrm{C}}\right.$, Fig. $\left.7 \mathrm{~d}\right)$, with peak values observed in the mid-afternoon. Given that our ${ }^{14} \mathrm{C}$-uptake rates for OSP14 likely represent a lower bound (corresponding to NPP, as opposed to GPP for OCE17), the absolute val- ues of $\Phi_{\mathrm{e}, \mathrm{C}}$ at OSP14 may be even higher than those presented in Fig. 7d.

As expected, values of $1 / \Phi_{C}$ followed a pattern very similar to $\Phi_{\mathrm{e}, \mathrm{C}}$, with high values observed under supersaturating light intensities, and this light-dependent effect enhanced under iron limitation (Fig. 7c).

\subsection{NPQ as optical signal}

Our simultaneous measurements of light absorption, ETRPSII and ${ }^{14} \mathrm{C}$ uptake allowed us to calculate conversion factors between these rates and observe variability in the electron requirement, $\Phi_{\mathrm{e}, \mathrm{C}}\left(\mathrm{mol} \mathrm{e}^{-} \mathrm{mol} \mathrm{C}^{-1}\right)$, and quantum efficiency, $\Phi_{\mathrm{C}}$ (mol C mol quanta absorbed ${ }^{-1}$ ), of carbon fixation. Estimates of $\Phi_{\mathrm{e}, \mathrm{C}}$ are crucial to derive high-spatial-resolution carbon-based productivity estimates from FRRF measurements (e.g. Hughes et al., 2018b; Lawrenz et al., 2013), while the quantum efficiency of carbon fixation is a key param- 

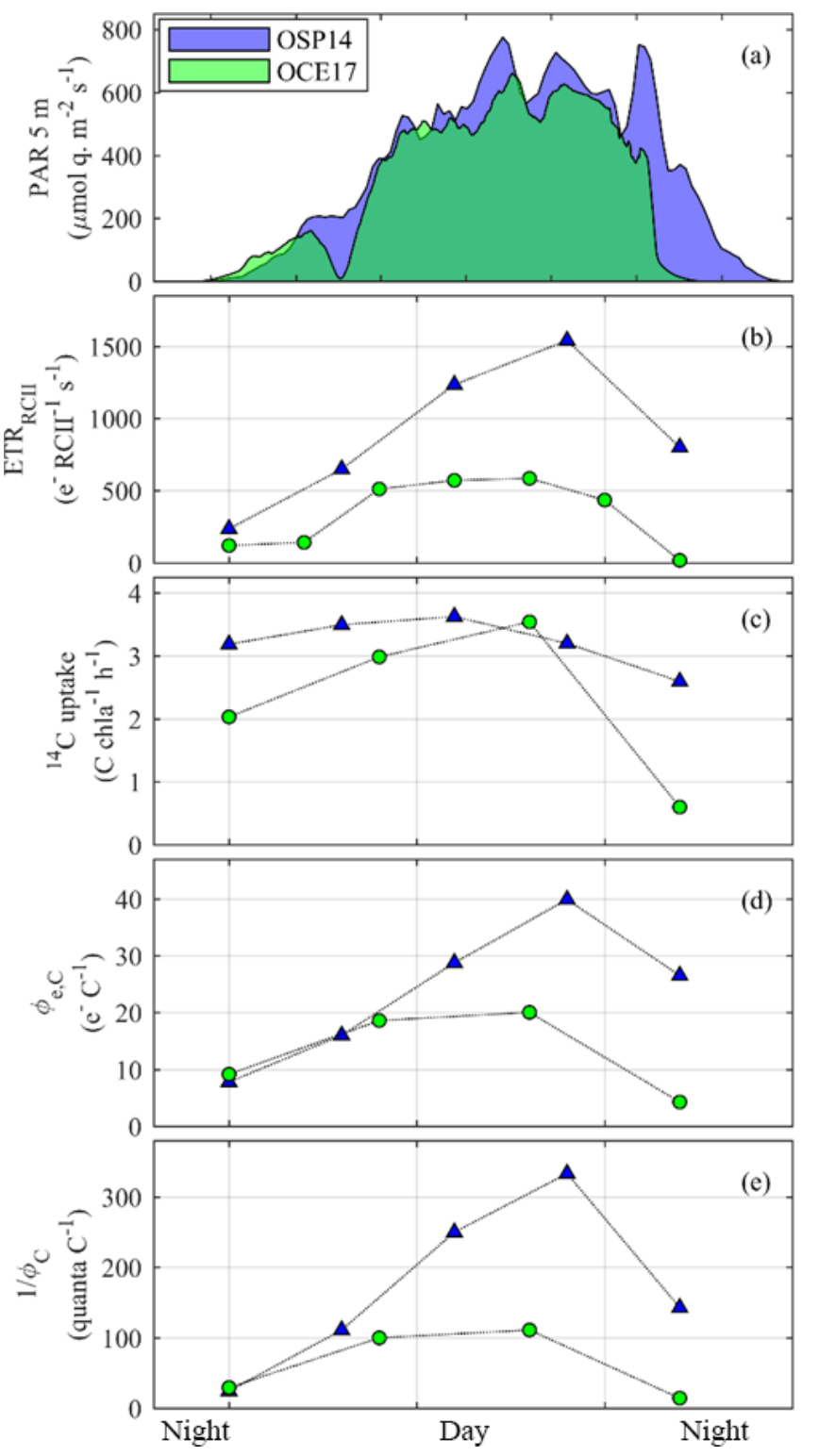

Figure 7. Comparison of diurnal trends observed at the OSP14 and OCE17 sampling sites. (a) PAR estimated for $5 \mathrm{~m}$ depth. (b) Rates of initial charge separation in individual RCII $\left(E^{2} R_{R C I I}\right)$. (c) Rates of ${ }^{14} \mathrm{C}$ uptake. (d) The electron requirement for carbon fixation $\left(\Phi_{\mathrm{e}, \mathrm{C}}\right)$. (e) The quantum requirement for carbon fixation $\left(1 / \Phi_{\mathrm{C}}\right)$. All rates and efficiencies correspond to in situ light availability at the time and depth of sampling.

eter in absorption-based phytoplankton primary productivity models (Marra et al., 2007; Silsbe et al., 2016; Zoffoli et al., 2018). Determination of these parameters in the field is labour intensive, and it is therefore desirable to identify proxies that can be autonomously monitored at high resolution. Our results suggest that estimates of NPQ, here derived from FRRF measurements, may provide useful information on both $\Phi_{\mathrm{e}, \mathrm{C}}$ and $\Phi_{\mathrm{C}}$. We argue, based on our results and previous work (Schuback et al., 2014, 2015, 2017), that NPQ is an optical signal amiable to high-resolution acquisition by autonomous sensors or remote sensing, which integrates the effects of multiple interacting environmental variables influencing photosynthetic energy conversion. As discussed in the following section, this parameter may hold unexploited potential to improve marine primary productivity estimates.

\subsubsection{The electron requirement for carbon fixation, $\Phi_{e, C}$}

Numerous studies have aimed to quantify variability in $\Phi_{e, C}$ in order to derive high-resolution, FRRF-based estimates of phytoplankton productivity in carbon units (reviewed by e.g. Hughes et al., 2018b; Lawrenz et al., 2013). These studies have shown that $\Phi_{\mathrm{e}, \mathrm{C}}$ can vary widely, due to physiological regulation on short timescales and taxonomic shifts on longer temporal or larger spatial scales. In general, higher values of $\Phi_{\mathrm{e}, \mathrm{C}}$ are found under conditions of high excitation pressure at the level of RCII (high light and/or low nutrients). Indeed, for both OCE17 and OSP14, maximum $\Phi_{\mathrm{e}, \mathrm{C}}$ was observed during high-irradiance periods in the afternoon, and $\Phi_{\mathrm{e}, \mathrm{C}}$, derived for in situ light availability, followed PAR levels over the diurnal cycle (Fig. 7d). However, the diurnal range of $\Phi_{e, C}$ differed between OCE17 andOSP14, with a significantly larger range and midday maximum in $\Phi_{\mathrm{e}, \mathrm{C}}$ in the iron-limited waters of OPS14 (Fig. 7d). This result suggests an enhanced need to dissipate excess electron pressure under iron-limiting conditions.

High excitation pressure also triggers the upregulation of heat dissipation mechanisms in the pigment antenna (here estimated as NPQNSV), and several studies have reported a correlation between $\Phi_{\mathrm{e}, \mathrm{C}}$ and $\mathrm{NPQ}_{\mathrm{NSV}}$ (Hughes et al., 2018a; Schuback et al., 2015, 2016b, 2017a; Zhu et al., 2017). We observed such a correlation at both of our sampling sites (Fig. 8a), but the slope of the NPQ ${ }_{\mathrm{NSV}}: \Phi_{\mathrm{e}, \mathrm{C}}$ correlation differed between the two sites (12.2 for OCE17 vs. 2.34 for OSP14; Fig. 8a). Several recent studies have similarly documented variability in the relationship between $\Phi_{\mathrm{e}, \mathrm{C}}$ and NPQNSV. For example, Hughes et al. (2018a) reported seasonally dependent slopes between NPQ $\mathrm{NSV}_{\mathrm{N}}$ and $\Phi_{\mathrm{e}, \mathrm{C}}$ at a sampling site off the coast of Australia. In a previous study (Schuback et al., 2017), we observed a strong correlation between NPQ $\mathrm{NSV}_{\text {and }} \Phi_{\mathrm{e}, \mathrm{C}} / n_{\mathrm{PSII}}$ in the upper mixed layer of the Arctic Ocean but only very weak NPQ ${ }_{N S v}$ and no apparent correlation with $\Phi_{\mathrm{e}, \mathrm{C}} / n_{\mathrm{PSII}}$ below the mixed layer.

Differences in experimental procedures and data analysis make it impossible to directly compare the slopes of $\mathrm{NPQ}_{\mathrm{NSV}}-\Phi_{\mathrm{e}, \mathrm{C}} / n_{\mathrm{PSII}}$ relationships between the different studies. Nonetheless, some general patterns do emerge. A strong correlation between $\mathrm{NPQ}_{\mathrm{NSV}}$ and $\Phi_{\mathrm{e}, \mathrm{C}}$ is likely to exist in all environments where phytoplankton must adapt to fluctuations in excitation pressure at the level of RCII. Such conditions result, for example, from high and fluctuating light intensities, nutrient limitation and cold temperatures. However, the substantial taxonomic variability in phy- 


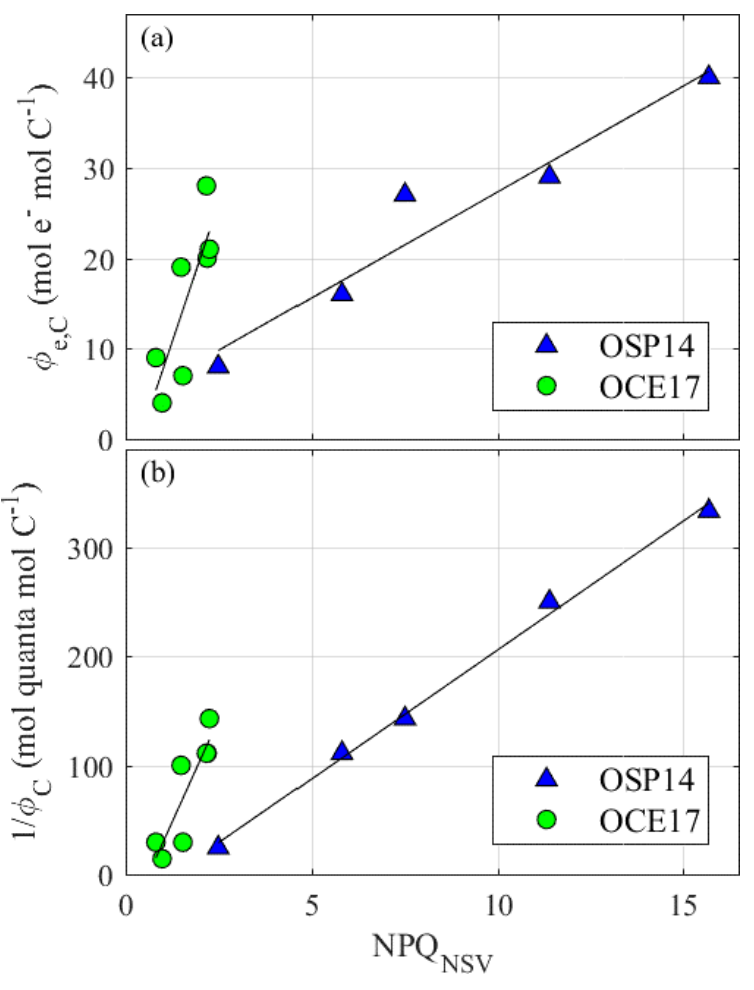

Figure 8. (a) Correlations between the electron requirement of carbon fixation, $\Phi_{\mathrm{e}, \mathrm{C}}$ and NPQNSV, both derived for in situ light intensity at the time and depth of sampling for each time point during daylight hours. OCE17: $\Phi_{\mathrm{e}, \mathrm{C}}=12.2 \cdot \mathrm{NPQ}_{\mathrm{NSV}}-4.53 ; R^{2}=0.68$; $n=7$. OSP14: $\Phi_{\mathrm{e}, \mathrm{C}}=2.34 \cdot \mathrm{NPQ}_{\mathrm{NSV}}+3.74 ; R^{2}=0.94, n=5$. (b) Correlations between the photon requirement of carbon fixation, $1 / \Phi_{\mathrm{C}}$ and $\mathrm{NPQ}_{\mathrm{NSV}}$, both derived for in situ light intensity at the time and depth of sampling for each time point during daylight hours. OCE17: $1 / \Phi_{C}=75 \cdot \mathrm{NPQ}_{\mathrm{NSV}}-46 ; R^{2}=0.68 ; n=7$. OSP14: $1 / \Phi_{\mathrm{C}}=23 \cdot \mathrm{NPQ}_{\mathrm{NSV}}+30 ; R^{2}=0.94 ; n=5$.

toplankton photosynthetic architecture and photo-physiology (e.g. Campbell et al., 1998; Kunath et al., 2012) makes it likely that $\mathrm{NPQ}_{\mathrm{NSV}}: \Phi_{\mathrm{e}, \mathrm{C}}$ relationships will require regional tuning.

Variability in the NPQ ${ }_{N S V}: \Phi_{e, C}$ relationship may limit the application of a single global approach to derive carbonbased productivity from FRRF data. Yet, such variability may hold inherent information about the physiological state of a phytoplankton assemblage and the bottom-up controls on primary productivity. For example, phytoplankton assemblages adapted to growth in high-light and/or low-nutrient environments appear to show stronger light-dependent increases in NPQNSv than $\Phi_{e, C}$, leading to a change in the slope of the correlation between these variables. This result reflects preferential changes in the pigment antenna configurations (leading to heat dissipation as NPQ), over alterations of the electron transport chain and upregulation of alternative electron sinks (affecting $\Phi_{e, C}$ ). In this way, the slope of the NPQ $\mathrm{NSV}_{\mathrm{e}}: \Phi_{\mathrm{e}, \mathrm{C}}$ correlation may reflect taxonomic differ- ences in evolutionary strategies to achieve balanced growth under varying environmental conditions.

\subsubsection{The quantum efficiency of carbon fixation, $\Phi_{C}$}

The quantum efficiency of carbon fixation $\left(\Phi_{C}\right)$, also referred to as photosynthetic efficiency, is defined as carbon fixed per unit of light absorbed. It is a fundamental biophysical parameter, which is poorly constrained in models of primary productivity (Hiscock et al., 2008; Silsbe et al., 2016; Sorensen and Siegel, 2001; Zoffoli et al., 2018). Regional variability in its maximum value $\left(\Phi_{\mathrm{C}-\max }\right)$, achieved under limiting light conditions, is evident in the comparison of our two study regions. The significantly lower values we observed at OSP14 $\left(0.038 \pm 0.019 \mathrm{~mol} \mathrm{C} \mathrm{mol} \mathrm{photon}^{-1}\right)$ relative to OCE17 $\left(0.078 \pm 0.019 \mathrm{~mol} \mathrm{C} \mathrm{mol} \mathrm{photon}^{-1}\right)$ are consistent with laboratory and field observations showing a lower maximum quantum efficiency under nutrient limitation and/or low temperatures and high-light environments (Babin et al., 1996b; Finenko et al., 2002; Marra et al., 2000; Morel, 1978; Ostrowska et al., 2012; Uitz et al., 2008).

The maximum quantum efficiency of carbon fixation is only achieved when photosynthesis is light-limited. At higher light intensities, absorbed light energy is increasingly redistributed to pathways other than ETR $_{\mathrm{RCII}}$ (fluorescence or heat, Fig. 1, process 1), and excess energy within the electron transport chain is channelled to pathways other than carbon fixation (thereby increasing $\Phi_{\mathrm{e}, \mathrm{C}}$, Fig. 1, processes 3 and 4). Consequently, values of $\Phi_{C}$ are expected to correlate with NPQNSV (Fig. 8b) in a manner similar to that described for $\Phi_{e, C}$ (Sect. 4.3.1). Indeed, NPQ has been extensively utilized as a proxy for variability in $\Phi_{C}$ in remote sensing algorithms of terrestrial primary productivity $(\mathrm{Ga}-$ mon et al., 1997; Garbulsky et al., 2011; Peñuelas et al., 2013). In these terrestrial applications, light use efficiency (LUE, which is equivalent to $\Phi_{\mathrm{C}}$ ) is estimated from the photochemical reflectance index (PRI), a proxy for NPQ derived from changes in reflectance band ratios, tracking changes in xanthophyll cycle (XC) pigments (e.g. Peñuelas et al., 2011). Relative to vascular plants, NPQ mechanisms in phytoplankton appear to be significantly more diverse and are less well understood (e.g. Goss and Lepetit, 2015; Lavaud and Goss, 2014). It is, therefore, unlikely that a PRI approach could be successfully applied to mixed phytoplankton assemblages across contrasting oceanic environments. We note, however, that light-dependent changes in pigment ratios have previously been correlated to $\Phi_{\mathrm{C}}$ in phytoplankton (e.g Babin et al. 1996a; Johnson et al. 2002; Vaillancourt et al., 2003; Prieto et al., 2007; Marra et al., 2000). Moreover, changes in pigment ratios have been successfully correlated to absorption band ratios of phytoplankton (Eisner et al., 2003; Eisner and Cowles, 2005; Méléder et al., 2018; Stuart et al., 2000). These results suggest that absorption band ratios may hold potential to improve estimates of $\Phi_{\mathrm{C}}$ at regional scales. 
A mechanistic coupling is expected between photoprotection and $\Phi_{C}$ across differing phytoplankton. Indeed, our results show that estimates of NPQ correlate well to measured values of $\Phi_{C}$ (Fig. 8b), suggesting that NPQ should be further examined as a proxy for $\Phi_{C}$. In the present study, we determined values of NPQ from FRRF measurements. However, other approaches to estimate NPQ in marine phytoplankton exist. These approaches have mostly been developed to correct for NPQ effects on phytoplankton Chl $a$ biomass estimates from in situ ChlF sensors (Biermann et al., 2015; Thomalla et al., 2018; Xing et al., 2018), without fully exploiting the information inherent in this signal.

While previous studies have shown that irradiance provides an easily measurable proxy for changes in $\Phi_{C}$ (Kiefer and Mitchell, 1983; Silsbe et al., 2016), the response of $\Phi_{C}$ to incident light will be modulated by other environmental factors, including nutrient availability and temperature. For example, the observed difference in $\Phi_{\mathrm{C} \text {-max }}$ between OSP14 and OCE17 cannot be explained by differences in instantaneous light availability, which was similar at the two sites (Fig. 7a). In contrast, the regional difference we observed in $\Phi_{\mathrm{C} \text {-max }}$ was well reflected in the extent of the diurnal NPQ response (Fig. 6f). NPQ thus provides an optical signal integrating a multitude of environmental controls on the photosynthetic apparatus and may help constrain variability in $\Phi_{\mathrm{C}}$, leading to improved marine primary productivity estimates.

\section{Conclusions}

The photosynthetic process plays a key role in the energy budget of phytoplankton metabolism, marine ecosystems and the global carbon cycle. Yet, models of marine primary productivity typically do not adequately account for the dynamic environmental controls on photosynthesis and variations in the transfer of absorbed photon energy to organic carbon. The present study aimed to enhance our understanding of the photo-physiological mechanisms maintaining energetic balance within the photosynthetic system of phytoplankton over diurnal timescales in contrasting marine environments.

Our results demonstrate how iron limitation affects the plasticity with which marine phytoplankton can optimize the use of light energy for carbon fixation. Low iron availability reduced the ability of phytoplankton to utilize diurnal increases in absorbed light energy for carbon fixation and increased the need for effective photoprotection. Based on our data, we suggest that optical measurements of NPQ hold untapped potential to assess energy conversion efficiencies and, in turn, increase our ability to monitor phytoplankton physiology and primary productivity over a range of ecologically relevant temporal and spatial scales.

Data availability. Data are available under https://doi.org/10.5281/zenodo.2616450 (Schuback, 2019).
Supplement. The supplement related to this article is available online at: https://doi.org/10.5194/bg-16-1381-2019-supplement.

Author contributions. NS designed and performed the experiments. NS and PDT wrote the manuscript.

Competing interests. The authors declare that they have no conflict of interest.

Acknowledgements. We thank the crew and expedition participants of both expeditions, in particular Mirkko Flecken for assistance during OSP14 and Sarah Rosengard for help during OCE17. NS would like to thank the students of the "Arctic Floating University 2018: Terra Novae" research and educational expedition, which needed so little supervision that she had time to write this manuscript.

Review statement. This paper was edited by Koji Suzuki and reviewed by two anonymous referees.

\section{References}

Alderkamp, A.-C., Mills, M. M., Van Dijken, G. L., Laan, P., Thuró Czy, C.-E., Gerringa, L. J. A., De Baar, H. J. W., Payne, C. D., Visser, R. J. W., Buma, A. G. J., and Arrigo, K. R.: Iron from melting glaciers fuels phytoplankton blooms in the Amundsen Sea (Southern Ocean): Phytoplankton characteristics and productivity, Deep-Sea Res. Pt. II, 71-76, 32-48, https://doi.org/10.1016/j.dsr2.2012.03.005, 2012.

Allen, A. E., Laroche, J., Maheswari, U., Lommer, M., Schauer, N., Lopez, P. J., Finazzi, G., Fernie, A. R., and Bowler, C.: Wholecell response of the pennate diatom Phaeodactylum tricornutum to iron starvation, P. Natl. Acad. Sci. USA, 105, 10438-10443, https://doi.org/10.1073/pnas.0711370105, 2008.

Babin, M., Morel, A., Claustre, H., Bricaud, A., Kolber, Z., and Falkowski, P. G.: Nitrogen- and irradiance-dependent variations of the maximum quantum yield of carbon fixation in eutrophic, mesotrophic and oligotrophic marine systems, Deep-Sea Res. Pt. I, 43, 1241-1272, https://doi.org/10.1016/0967-0637(96)000581, 1996a.

Behrenfeld, M. J., O’Malley, R. T., Siegel, D. A., McClain, C. R., Sarmiento, J. L., Feldman, G. C., Milligan, A. J., Falkowski, P. G., Letelier, R. M., and Boss, E. S.: Climate-driven trend in contemporary ocean productivity, Nature, 444, 752-755, https://doi.org/10.1038/nature05317, 2006.

Behrenfeld, M. J., O’Malley, R. T., Boss, E. S., Westberry, T. K., Graff, J. R., Halsey, K. H., Milligan, A. J., Siegel, D. A., and Brown, M. B.: Revaluating ocean warming impacts on global phytoplankton, Nat. Clim. Change, 6, 323-330, https://doi.org/10.1038/nclimate2838, 2016.

Bidigare, R. R., Ondrusek, M. E., Morrow, J. H., and Kiefer, D. A.: In-vivo absorption properties of algal pigments, vol. 1302, edited by: Spinrad, R. W., International Society for Optics and Photonics, p. 290, 1990. 
Biermann, L., Guinet, C., Bester, M., Brierley, A., and Boehme, L.: An alternative method for correcting fluorescence quenching, Ocean Sci., 11, 83-91, https://doi.org/10.5194/os-11-83-2015, 2015.

Boyd, P. W., Watson, A. J., Law, C. S., Abraham, E. R., Trull, T., Murdoch, R., Bakker, D. C., Bowie, A. R., Buesseler, K. O., Chang, H., Charette, M., Croot, P., Downing, K., Frew, R., Gall, M., Hadfield, M., Hall, J., Harvey, M., Jameson, G., LaRoche, J., Liddicoat, M., Ling, R., Maldonado, M. T., McKay, R. M., Nodder, S., Pickmere, S., Pridmore, R., Rintoul, S., Safi, K., Sutton, P., Strzepek, R., Tanneberger, K., Turner, S., Waite, A., and Zeldis, J.: A mesoscale phytoplankton bloom in the polar Southern Ocean stimulated by iron fertilization, Nature, 407, 695-702, https://doi.org/10.1038/35037500, 2000.

Bricaud, A. and Stramski, D.: Spectral absorption coefficients of living phytoplankton and nonalgal biogenous matter: A comparison between the Peru upwelling areaand the Sargasso Sea, Limnol. Oceanogr., 35, 562-582, https://doi.org/10.4319/lo.1990.35.3.0562, 1990.

Bricaud, A., Babin, M., Morel, A., and Claustre, H.: Variability in the chlorophyll-specific absorption coefficients of natural phytoplankton: Analysis and parameterization, J. Geophys. Res., 100, 13321, https://doi.org/10.1029/95JC00463, 1995.

Burt, W. J., Westberry, T. K., Behrenfeld, M. J., Zeng, C., Izett, R. W., and Tortell, P. D.: Carbon: Chlorophyll ratios and net primary productivity of Subarctic Pacific surface waters derived from autonomous shipboard sensors, Global Biogeochem. Cy., 32, 267288, https://doi.org/10.1002/2017GB005783, 2018.

Campbell, D., Hurry, V., Clarke, A. K., Gustafsson, P., and Oquist, G.: Chlorophyll fluorescence analysis of cyanobacterial photosynthesis and acclimation, Microbiol. Mol. Biol. Rev., 62, 66783, https://doi.org/10.1016/S0735-1097(85)80016-4, 1998.

Claustre, H.: The trophic status of various oceanic provinces as revealed by phytoplankton pigment signatures, Limnol. Oceanogr., 39, 1206-1210, https://doi.org/10.4319/lo.1994.39.5.1206, 1994.

Corno, G., Letelier, R. M., Abbott, M. R., and Karl, D. M.: Assessing primary production variability in the North $\mathrm{Pa}-$ cific subtropical gyre: A comparison of fast repetition rate fluorometry and ${ }^{14} \mathrm{C}$ measurements, J. Phycol., 42, 51-60, https://doi.org/10.1111/j.1529-8817.2006.00163.x, 2006.

Davey, M. and Geider, R. J.: Impact of iron limitation on the photosynthetic apparatus of the diatom Chaetoceros Muelleri (Bacillariophyceae), J. Phycol., 37, 987-1000, https://doi.org/10.1046/j.1529-8817.2001.99169.x, 2001.

Eisner, L. B. and Cowles, T. J.: Spatial variations in phytoplankton pigment ratios, optical properties, and environmental gradients in Oregon coast surface waters, J. Geophys. Res. Pt. C, 110, 1-17, https://doi.org/10.1029/2004JC002614, 2005.

Eisner, L. B., Twardowski, M. S., Cowles, T. J., and Perry, M. J.: Resolving phytoplankton photoprotective?: Photosynthetic carotenoid ratios on fine scales using in situ spectral absorption measurements, Limnol. Oceanogr., 48, 632-646, https://doi.org/10.4319/lo.2003.48.2.0632, 2003.

Falkowski, P. G. and Raven, J. A.: Aquatic Photosynthesis, Princton University Press, 1997.

Finenko, Z., Churilova, T., Sosik, H. M., and Basturk, O.: Variability of photosynthetic parameters of the surface phytoplankton in the Black Sea, Oceanology, 42, 53-67, https://doi.org/10.1016/S0735-1097(85)80016-4, 2002.

Fujiki, T., Suzue, T., Kimoto, H., and Saino, T.: Photosynthetic electron transport in Dunaliella tertiolecta (Chlorophyceae) measured by fast repetition rate fluorometry: relation to carbon assimilation, J. Plankton Res., 29, 199-208, https://doi.org/10.1093/plankt/fbm007, 2007.

Gamon, J. A., Serrano, L., and Surfus, J. S.: The photochemical reflectance index: an optical indicator of photosynthetic radiation use efficiency across species, functional types, and nutrient levels, Oecologia, 112, 492-501, https://doi.org/10.1007/s004420050337, 1997.

Garbulsky, M. F., Peñuelas, J., Gamon, J., Inoue, Y., and Filella, I.: The photochemical reflectance index (PRI) and the remote sensing of leaf, canopy and ecosystem radiation use efficiencies, A review and meta-analysis, Remote Sens. Environ., 115, 281-297, https://doi.org/10.1016/j.rse.2010.08.023, 2011.

Geider, R. J., Delucia, E. H., Falkowski, P. G., Finzi, A. C., Grime, J. P., Grace, J., Kana, T. M., La Roche, J., Long, S. P., Osborne, B. A., Platt, T., Prentice, I. C., Raven, J. A., Schlesinger, W. H., Smetacek, V., Stuart, V., Sathyendranath, S., Thomas, R. B., Vogelmann, T. C., Williams, P., and Woodward, F. I.: Primary productivity of planet earth: biological determinants and physical constraints in terrestrial and aquatic habitats, Glob. Change Biol., 7, 849-882, https://doi.org/10.1046/j.1365-2486.2001.00448.x, 2001.

Goss, R. and Lepetit, B.: Biodiversity of NPQ, J. Plant Physiol., 172, 13-32, https://doi.org/10.1016/j.jplph.2014.03.004, 2015.

Greene, R. M., Geider, R. J., and Falkowski, P. G.: Effect of iron limitation on photosynthesis in a marine diatom, Limnol. Oceanogr., 36, 1772-1782, https://doi.org/10.4319/lo.1991.36.8.1772, 1991.

Greene, R. M., Geider, R. J., Kolber, Z., and Falkowski, P. G.: Ironinduced changes in light harvesting and photochemical energy conversion processes in eukaryotic marine algae, Plant Physiol., 100, 565-75, https://doi.org/10.1104/PP.100.2.565, 1992.

Halsey, K. H. and Jones, B. M.: Phytoplankton Strategies for Photosynthetic Energy Allocation, Ann. Rev. Mar. Sci., 7, 265-297, https://doi.org/10.1146/annurev-marine-010814-015813, 2015.

Hancke, K., Dalsgaard, T., Sejr, M. K., Markager, S., and Glud, R. N.: Phytoplankton Productivity in an arctic fjord (West Greenland): Estimating electron requirements for carbon fixation and oxygen production, edited by: A. M. Cockshutt, PLoS One, 10, e0133275, https://doi.org/10.1371/journal.pone.0133275, 2015.

Harris, G. P.: Phytoplankton ecology: structure, function, and fluctuation, Chapman and Hall, 1986.

Herr, A., Dacey, J., Kiene, R., McCulloch, R., Schuback, N., and Tortell P. D.: Potential roles of dimethysulfoxide in regional sulfur cycling and phytoplankton physiological ecology in the NE Subarctic Pacific, in review, 2019.

Hiscock, M. R., Lance, V. P., Apprill, A. M., Bidigare, R. R., Johnson, Z. I., Mitchell, B. G., Smith, W. O., and Barber, R. T.: Photosynthetic maximum quantum yield increases are an essential component of the Southern Ocean phytoplankton response to iron, P. Natl. Acad. Sci. USA, 105, 4775-4780, https://doi.org/10.1073/pnas.0705006105, 2008.

Hoegh-Guldberg, O. and Bruno, J. F.: The impact of climate change on the world's marine ecosystems, Science, 328, 1523-1528, https://doi.org/10.1126/science.1189930, 2010. 
Hoppe, C. J. M., Hassler, C. S., Payne, C. D., Tortell, P. D., Rost, B., and Trimborn, S.: Iron Limitation Modulates Ocean Acidification Effects on Southern Ocean Phytoplankton Communities, PLoS One, 8, e79890, https://doi.org/10.1371/journal.pone.0079890, 2013.

Hughes, D. J., Varkey, D., Doblin, M. A., Ingleton, T., Mcinnes, A., Ralph, P. J., van Dongen-Vogels, V., and Suggett, D. J.: Impact of nitrogen availability upon the electron requirement for carbon fixation in Australian coastal phytoplankton communities, Limnol. Oceanogr., 63, 1891-1910, https://doi.org/10.1002/lno.10814, 2018a.

Hughes, D. J., Campbell, D. A., Doblin, M. A., Kromkamp, J. C., Lawrenz, E., Moore, C. M., Oxborough, K., Prášil, O., Ralph, P. J., Alvarez, M. F., and Suggett, D. J.: Roadmaps and detours: Active chlorophyll- $a$ assessments of primary productivity across marine and freshwater systems, Environ. Sci. Technol., 52, 12039-12054, https://doi.org/10.1021/acs.est.8b03488, 2018b.

Huner, N. P. ., Öquist, G., and Sarhan, F.: Energy balance and acclimation to light and cold, Trends Plant Sci., 3, 224-230, https://doi.org/10.1016/S1360-1385(98)01248-5, 1998.

Ivanov, A. G., Park, Y.-I., Miskiewicz, E., Raven, J. A., Huner, N. P. A., and Öquist, G.: Iron stress restricts photosynthetic intersystem electron transport in Synechococcus sp. PCC 7942, FEBS Lett., 485, 173-177, https://doi.org/10.1016/S00145793(00)02211-0, 2000.

Johnson, Z., Bidigare, R. R., Goericke, R., Marra, J., Trees, C., and Barber, R. T.: Photosynthetic physiology and physicochemical forcing in the Arabian Sea, 1995, Deep-Sea Res. Pt. I, 49, 415436, https://doi.org/10.1016/S0967-0637(01)00068-1, 2002.

Kiefer, D. A. and Mitchell, B. G.: A simple, steady state description of phytoplankton growth based on absorption cross section and quantum efficiency, Limnol. Oceanogr., 28, 770-776, https://doi.org/10.4319/lo.1983.28.4.0770, 1983.

Kirk, J. T. O.: Light and photosynthesis in aquatic ecosystems, 2nd edn., J. Mar. Biol. Assoc. UK, 74, 987, https://doi.org/10.1017/S0025315400044180, 1994.

Kolber, Z. and Falkowski, P. G.: Use of active fluorescence to estimate phytoplankton photosynthesis in situ, Limnol. Oceanogr., 38, 1646-1665, https://doi.org/10.4319/lo.1993.38.8.1646, 1993.

Kolber, Z. S., Barber, R. T., Coale, K. H., Fitzwateri, S. E., Greene, R. M., Johnson, K. S., Lindley, S., and Falkowski, P. G.: Iron limitation of phytoplankton photosynthesis in the equatorial Pacific Ocean, Nature, 371, 145-149, https://doi.org/10.1038/371145a0, 1994.

Kolber, Z. S., Prášil, O., and Falkowski, P. G.: Measurements of variable chlorophyll fluorescence using fast repetition rate techniques: defining methodology and experimental protocols, Biochim. Biophys. Acta-Bioenerg., 1367, 88-106, https://doi.org/10.1016/S0005-2728(98)00135-2, 1998

Kromkamp, J. C. and Forster, R. M.: The use of variable fluorescence measurements in aquatic ecosystems: Differences between multiple and single turnover measuring protocols and suggested terminology, Eur. J. Phycol., 38, 103-112, https://doi.org/10.1080/0967026031000094094, 2003.

Kunath, C., Jakob, T., and Wilhelm, C.: Different phycobilin antenna organisations affect the balance between light use and growth rate in the cyanobacterium Microcystis aeruginosa and in the cryptophyte Cryptomonas ovata, Photosynth. Res., 111, 173-183, https://doi.org/10.1007/s11120-011-9715-4, 2012.

Lavaud, J. and Goss, R.: The peculiar features of nonphotochemical fluorescence quenching in diatoms and brown algae, in: Non-Photochemical Quenching and Energy Dissipation in Plants, Algae and Cyanobacteria, edited by: Demmig-Adams, B., Garab, G., and Adams III, W. W., Govindjee, Springer, Berlin, Heidelberg, Germany, 421-443, 2014.

Lawrenz, E., Silsbe, G., Capuzzo, E., Ylöstalo, P., Forster, R. M., Simis, S. G. H., Prášil, O., Kromkamp, J. C., Hickman, A. E., Moore, C. M., Forget, M.-H., Geider, R. J., and Suggett, D. J.: Predicting the electron requirement for carbon fixation in seas and oceans, PLoS One, 8, e58137, https://doi.org/10.1371/journal.pone.0058137, 2013.

Le, C., Li, Y., Zha, Y., and Sun, D.: Specific absorption coefficient and the phytoplankton package effect in Lake Taihu, China, Hydrobiologia, 619, 27-37, https://doi.org/10.1007/s10750-0089579-6, 2009.

Lee, Z., Marra, J., Perry, M. J., and Kahru, M.: Estimating oceanic primary productivity from ocean color remote sensing: A strategic assessment, J. Mar. Syst., 149, 50-59, https://doi.org/10.1016/J.JMARSYS.2014.11.015, 2015.

Letelier, R. M., White, A. E., Bidigare, R. R., Barone, B., Church, M. J., and Karl, D. M.: Light absorption by phytoplankton in the North Pacific Subtropical Gyre, Limnol. Oceanogr., 62, 15261540, https://doi.org/10.1002/lno.10515, 2017.

Marra, J., Trees, C. C., Bidigare, R. R., and Barber, R. T.: Pigment absorption and quantum yields in the Arabian Sea, DeepSea Res. Pt. II, 47, 1279-1299, https://doi.org/10.1016/S09670645(99)00144-7, 2000.

Marra, J., Trees, C. C., and O'Reilly, J. E.: Phytoplankton pigment absorption: A strong predictor of primary productivity in the surface ocean, Deep-Sea Res. Pt. I, 54, 155-163, https://doi.org/10.1016/J.DSR.2006.12.001, 2007.

McKew, B. A., Davey, P., Finch, S. J., Hopkins, J., Lefebvre, S. C., Metodiev, M. V., Oxborough, K., Raines, C. A., Lawson, T., and Geider, R. J.: The trade-off between the light-harvesting and photoprotective functions of fucoxanthin-chlorophyll proteins dominates light acclimation in Emiliania huxleyi (clone CCMP 1516), New Phytol., 200, 74-85, https://doi.org/10.1111/nph.12373, 2013.

Méléder, V., Jesus, B., Barnett, A., Barillé, L., and Lavaud, J.: Microphytobenthos primary production estimated by hyperspectral reflectance, edited by: Schmitt, F. G., PLoS One, 13, e0197093, https://doi.org/10.1371/journal.pone.0197093, 2018.

Milligan, A. J., Halsey, K. H., and Behrenfeld, M. J.: Advancing interpretations of ${ }^{14} \mathrm{C}$-uptake measurements in the context of phytoplankton physiology and ecology: Fig. 1., J. Plankton Res., 37, 692-698, https://doi.org/10.1093/plankt/fbv051, 2015.

Mitchell, B. G., Bricaud, A., Carder, K., Cleveland, J., and Ferrari, G.: Determination of spectral absorption coefficients of particles , dissolved material and phytoplankton for discrete water samples, Ocean Opt. Protoc. Satell. Ocean Color Sens. Valid. Revis 2, 125-153, 2000.

Moore, C. M., Seeyave, S., Hickman, A. E., Allen, J. T., Lucas, M. I., Planquette, H., Pollard, R. T., and Poulton, A. J.: Iron-light interactions during the CROZet natural iron bloom and EXport experiment (CROZEX) I: Phytoplankton growth 
and photophysiology, Deep-Sea Res. Pt. II, 54, 2045-2065, https://doi.org/10.1016/j.dsr2.2007.06.011, 2007.

Morel, A.: Available, usable, and stored radiant energy in relation to marine photosynthesis, Deep-Sea Res., 25, 673-688, https://doi.org/10.1016/0146-6291(78)90623-9, 1978.

Morel, A. and Bricaud, A.: Theoretical results concerning light absorption in a discrete medium, and application to specific absorption of phytoplankton, Deep-Sea Res. Pt. A, 28, 1375-1393, https://doi.org/10.1016/0198-0149(81)90039-X, 1981.

Niyogi, K. K.: Safety valves for photosynthesis, Curr. Opin. Plant Biol., 3, 455-460, https://doi.org/10.1016/S13695266(00)00113-8, 2000.

Ostrowska, M., Woźniak, B., and Dera, J.: Modelled quantum yields and energy efficiency of fluorescence, photosynthesis and heat production by phytoplankton in the World Ocean, Oceanologia, 54, 565-610, https://doi.org/10.5697/OC.54-4.565, 2012.

Oxborough, K. and Baker, N. R.: Resolving chlorophyll a fluorescence images of photosynthetic efficiency into photochemical and non-photochemical components - calculation of $q_{P}$ and $F_{v} / F_{m}$; without measuring $F_{o}$, Photosynth. Res., 54, 135-142, https://doi.org/10.1023/A:1005936823310, 1997.

Pei, S. and Laws, E. A.: Does the ${ }^{14} \mathrm{C}$ method estimate net photosynthesis? Implications from batch and continuous culture studies of marine phytoplankton, Deep-Sea Res. Pt. I, 82, 1-9, https://doi.org/10.1016/j.dsr.2013.07.011, 2013.

Peñuelas, J., Garbulsky, M. F., and Filella, I.: Photochemical reflectance index (PRI) and remote sensing of plant $\mathrm{CO}_{2}$ uptake, New Phytol., 191, 596-599, https://doi.org/10.1111/j.14698137.2011.03791.x, 2011.

Peñuelas, J., Marino, G., LLusia, J., Morfopoulos, C., FarréArmengol, G., and Filella, I.: Photochemical reflectance in$\operatorname{dex}$ as an indirect estimator of foliar isoprenoid emissions at the ecosystem level, Nat. Commun., 4, 2604, https://doi.org/10.1038/ncomms3604, 2013.

Petrou, K., Trimborn, S., Rost, B., Ralph, P. J., and Hassler, C. S.: The impact of iron limitation on the physiology of the Antarctic diatom Chaetoceros simplex, Mar. Biol., 161, 925-937, https://doi.org/10.1007/s00227-014-2392-z, 2014.

Powles, S. B.: Photoinhibition of photosynthesis induced by visible light, Ann. Rev. Plant Physio., 35, 15-44, https://doi.org/10.1146/annurev.pp.35.060184.000311, 1984.

Prieto, L., Vaillancourt, R. D., Hales, B., and Marra, J.: On the relationship between carbon fixation efficiency and bio-optical characteristics of phytoplankton, J. Plankton Res., 30, 43-56, https://doi.org/10.1093/plankt/fbm093, 2007.

Raven, J. A., Evans, M. C. W., and Korb, R. E.: The role of trace metals in photosynthetic electron transport in $\mathrm{O}_{2}$-evolving organisms, Photosynth. Res., 60, 111-150, https://doi.org/10.1023/A:1006282714942, 1999.

Roncel, M., González-Rodríguez, A. A., Naranjo, B., BernalBayard, P., Lindahl, A. M., Hervás, M., Navarro, J. A., and Ortega, J. M.: Iron deficiency induces a partial inhibition of the photosynthetic electron transport and a high sensitivity to light in the diatom Phaeodactylum tricornutum, Front. Plant Sci., 7, 1050, https://doi.org/10.3389/fpls.2016.01050, 2016.

Sakshaug, E., Bricaud, A., Dandonneau, Y., Falkowski, P. G., Kiefer, D. A., Legendre, L., Morel, A., Parslow, J., and Takahashi, M.: Parameters of photosynthesis: Definitions, theory and interpretation of results, J. Plankton Res., 19, 1637-1670, https://doi.org/10.1093/plankt/19.11.1637, 1997.

Schuback, N., Schallenberg, C., Duckham, C., Maldonado, M. T., and Tortell, P. D.: Interacting effects of light and iron availability on the coupling of photosynthetic electron transport and $\mathrm{CO}_{2-}$ assimilation in marine phytoplankton, PLoS One, 10, e0133235, https://doi.org/10.1371/journal.pone.0133235, 2015.

Schuback, N., Flecken, M., Maldonado, M. T., and Tortell, P. D.: Diurnal variation in the coupling of photosynthetic electron transport and carbon fixation in iron-limited phytoplankton in the NE subarctic Pacific, Biogeosciences, 13, 1019-1035, https://doi.org/10.5194/bg-13-1019-2016, 2016.

Schuback, N., Hoppe, C. J. M., Tremblay, J.-É., Maldonado, M. T., and Tortell, P. D.: Primary productivity and the coupling of photosynthetic electron transport and carbon fixation in the Arctic Ocean, Limnol. Oceanogr., 62, 898-921, https://doi.org/10.1002/lno.10475, 2017.

Schuback, N.: Diurnal regulation of photosynthetic light absorption, electron transport and carbon fixation in two contrasting oceanic environments, Biogeosciences, https://doi.org/10.5194/bg-2018524, 2019.

Silsbe, G. M., Behrenfeld, M. J., Halsey, K. H., Milligan, A. J., and Westberry, T. K.: The CAFE model: A net production model for global ocean phytoplankton, Global Biogeochem. Cy., 30, 17561777, https://doi.org/10.1002/2016GB005521, 2016.

Sorensen, J. C. and Siegel, D. A.: Variability of the effective quantum yield for carbon assimilation in the Sargasso Sea, DeepSea Res. Pt. II, 48, 2005-2035, https://doi.org/10.1016/S09670645(00)00170-3, 2001.

Strzepek, R. F. and Harrison, P. J.: Photosynthetic architecture differs in coastal and oceanic diatoms, Nature, 431, 689-692, https://doi.org/10.1038/nature02954, 2004.

Strzepek, R. F., Hunter, K. A., Frew, R. D., Harrison, P. J., and Boyd, P. W.: Iron-light interactions differ in Southern Ocean phytoplankton, Limnol. Oceanogr., 57, 1182-1200, https://doi.org/10.4319/lo.2012.57.4.1182, 2012.

Stuart, V., Sathyendranath, S., Head, E. J. H., Platt, T., Irwin, B., and Maass, H.: Bio-optical characteristics of diatom and prymnesiophyte populations in the Labrador Sea, Mar. Ecol. Prog. Ser., 201, 91-106, https://doi.org/10.3354/meps201091, 2000.

Suggett, D., Moore, C., and Geider, R.: Estimating Aquatic Productivity from Active Fluorescence Measurements, in: Chlorophyll a Fluorescence in Aquatic Sciences: Methods and Applications, Springer Netherlands, Dordrecht, 103-127, 2010.

Suggett, D. J., MacIntyre, H. L., and Geider, R. J.: Evaluation of biophysical and optical determinations of light absorption by photosystem II in phytoplankton, Limnol. Oceanogr. Method., 2, 316-332, https://doi.org/10.4319/lom.2004.2.316, 2004.

Taucher, J. and Oschlies, A.: Can we predict the direction of marine primary production change under global warming?, Geophys. Res. Lett., 38, LO2603, https://doi.org/10.1029/2010GL045934, 2011.

Terauchi, A. M., Peers, G., Kobayashi, M. C., Niyogi, K. K., and Merchant, S. S.: Trophic status of Chlamydomonas reinhardtii influences the impact of iron deficiency on photosynthesis, Photosynth. Res., 105, 39-49, https://doi.org/10.1007/s11120-0109562-8, 2010.

Thomalla, S. J., Moutier, W., Ryan-Keogh, T. J., Gregor, L., and Schütt, J.: An optimized method for correcting flu- 
orescence quenching using optical backscattering on autonomous platforms, Limnol. Oceanogr. Method., 16, 132-144, https://doi.org/10.1002/lom3.10234, 2018.

Uitz, J., Claustre, H., Morel, A., and Hooker, S. B.: Vertical distribution of phytoplankton communities in open ocean: An assessment based on surface chlorophyll, J. Geophys. Res., 111, C08005, https://doi.org/10.1029/2005JC003207, 2006.

Uitz, J., Huot, Y., Bruyant, F., Babin, M., and Claustre, H.: Relating phytoplankton photophysiological properties to community structure on large scales, Limnol. Oceanogr., 53, 614-630, https://doi.org/10.4319/1o.2008.53.2.0614, 2008.

Vaillancourt, R. D., Marra, J., Barber, R. T., and Smith, W. O.: Primary productivity and in situ quantum yields in the Ross Sea and Pacific sector of the Antarctic Circumpolar Current, DeepSea Res. Pt. II, 50, 559-578, https://doi.org/10.1016/S09670645(02)00584-2, 2003.

Vassiliev, I. R., Kolber, Z., Wyman, K. D., Mauzerall, D., Shukla, V. K., and Falkowski, P. G.: Effects of Iron Limitation on Photosystem II Composition and Light Utilization in Dunaliella tertiolecta, Plant Physiol., 109, 963-972, https://doi.org/10.1104/PP.109.3.963, 1995.

Vidussi, F., Claustre, H., Manca, B. B., Luchetta, A., and Marty, J.-C.: Phytoplankton pigment distribution in relation to upper thermocline circulation in the eastern Mediterranean Sea during winter, J. Geophys. Res.-Ocean., 106, 19939-19956, https://doi.org/10.1029/1999JC000308, 2001.
Webb, W. L., Newton, M., and Starr, D.: Carbon dioxide exchange of Alnus rubra, Oecologia, 17, 281-291, https://doi.org/10.1007/BF00345747, 1974.

Woźniak, B., Dera, J., Ficek, D., Majchrowski, R., Kaczmarek, S., Ostrowska, M., and Koblentz-Mishke, O. I.: Modelling the influence of acclimation on the absorption properties of marine phytoplankton, Oceanologia, 41, 187-210, 1999.

Xing, X., Briggs, N., Boss, E., and Claustre, H.: Improved correction for non-photochemical quenching of in situ chlorophyll fluorescence based on a synchronous irradiance profile, Opt. Express, 26, 24734, https://doi.org/10.1364/OE.26.024734, 2018.

Xu, K., Grant-Burt, J. L., Donaher, N., and Campbell, D. A.: Connectivity among photosystem II centers in phytoplankters: Patterns and responses, Biochim. Biophys. Acta-Bioenerg., 1858, 459-474, https://doi.org/10.1016/j.bbabio.2017.03.003, 2017.

Yruela, I.: Transition metals in plant photosynthesis, Metallomics, 5, 1090, https://doi.org/10.1039/c3mt00086a, 2013.

Zhu, Y., Ishizaka, J., Tripathy, S., Wang, S., Sukigara, C., Goes, J., Matsuno, T., and Suggett, D.: Relationship between light, community composition and the electron requirement for carbon fixation in natural phytoplankton, Mar. Ecol. Prog. Ser., 580, 83-100, https://doi.org/10.3354/meps12310, 2017.

Zoffoli, M. L., Lee, Z., and Marra, J. F.: Regionalization and dynamic parameterization of quantum yield of photosynthesis to improve the ocean primary production estimates from remote sensing, Front. Mar. Sci., 5, 446, https://doi.org/10.3389/fmars.2018.00446, 2018. 